\title{
Purinergic receptors in the endocrine and exocrine pancreas
}

\author{
I. Novak
}

Received: 16 May 2007 / Accepted: 6 November 2007 /Published online: 11 December 2007

(C) Springer Science + Business Media B.V. 2007

\begin{abstract}
The pancreas is a complex gland performing both endocrine and exocrine functions. In recent years there has been increasing evidence that both endocrine and exocrine cells possess purinergic receptors, which influence processes such as insulin secretion and epithelial ion transport. Most commonly, these processes have been viewed separately. In $\beta$ cells, stimulation of $\mathrm{P} 2 \mathrm{Y}_{1}$ receptors amplifies secretion of insulin in the presence of glucose. Nucleotides released from secretory granules could also contribute to autocrine/paracrine regulation in pancreatic islets. In addition to $\mathrm{P}_{2} \mathrm{Y}_{1}$ receptors, there is also evidence for other $\mathrm{P} 2$ and adenosine receptors in $\beta$ cells ( $\mathrm{P} 2 \mathrm{Y}_{2}$, $\mathrm{P}_{2} \mathrm{Y}_{4}, \mathrm{P}_{2} \mathrm{Y}_{6}, \mathrm{P} 2 \mathrm{X}$ subtypes and $\mathrm{A}_{1}$ receptors) and in glucagon-secreting $\alpha$ cells ( $\mathrm{P} 2 \mathrm{X}_{7}, \mathrm{~A}_{2}$ receptors). In the exocrine pancreas, acini release ATP and ATP-hydrolysing and ATP-generating enzymes. P2 receptors are prominent in pancreatic ducts, and several studies indicate that $\mathrm{P}_{2} \mathrm{Y}_{2}$, $\mathrm{P} 2 \mathrm{Y}_{4}, \mathrm{P} 2 \mathrm{Y}_{11}, \mathrm{P} 2 \mathrm{X}_{4}$ and $\mathrm{P} 2 \mathrm{X}_{7}$ receptors could regulate secretion, primarily by affecting $\mathrm{Cl}^{-}$and $\mathrm{K}^{+}$channels and intracellular $\mathrm{Ca}^{2+}$ signalling. In order to understand the physiology of the whole organ, it is necessary to consider the full complement of purinergic receptors on different cells as well as the structural and functional relation between various cells within the whole organ. In addition to the possible physiological function of purinergic receptors, this review analyses whether the receptors could be potential therapeutic targets for drug design aimed at treatment of pancreatic diseases.
\end{abstract}

I. Novak $(\bowtie)$

Department of Biosciences, University of Copenhagen,

August Krogh Building, Universitetsparken 13,

2100 Copenhagen Ø, Denmark

e-mail: inovak@aki.ku.dk
Keywords Adenosine receptors - ATP release - Beta cell . BK channels · Cystic fibrosis · CFTR · Diabetes · Glucagon · IK channels $\cdot$ Pancreatitis

\begin{tabular}{|c|c|}
\hline \multicolumn{2}{|c|}{ Abbreviations } \\
\hline $\mathrm{AC}$ & adenylate cyclase \\
\hline BK & big conductance $\mathrm{K}^{+}$channel \\
\hline BzATP & 2'\&3'-O-(4-benzoyl-benzoyl)-ATP \\
\hline CFTR & cystic fibrosis transmembrane regulator \\
\hline CX & connexin \\
\hline DAG & diacylglycerol \\
\hline ERK & extracellular signal regulated kinase \\
\hline GLP-1 & glucagon-like peptide-1 \\
\hline $\mathrm{IK}$ & intermediate conductance $\mathrm{K}^{+}$channel \\
\hline $\mathrm{IP}_{3}$ & inositol $1,4,5$ triphosphate \\
\hline NBC & sodium bicarbonate cotransporter \\
\hline NECA & adenosine- $5^{\prime} N$-ethylcarboxamide \\
\hline NHE & sodium hydrogen exchanger \\
\hline $\mathrm{NO}$ & nitric oxide \\
\hline NTPDase & nucleoside triphosphate diphosphohydrolase \\
\hline PKA & protein kinase A \\
\hline $\mathrm{PKC}$ & protein kinase $\mathrm{C}$ \\
\hline $\mathrm{PLA}_{2}$ & protein lipase $A_{2}$ \\
\hline PLC & phospholipase C \\
\hline SK & small conductance $\mathrm{K}^{+}$channel \\
\hline VIP & vasoactive intestinal peptide \\
\hline
\end{tabular}

\section{Structural and functional basis for pancreatic function}

Endocrine cells in the islets of Langerhans constitute only $3-5 \%$ of the tissue mass of the pancreas. The islets of Langerhans are dispersed throughout the organ and comprise $\alpha, \beta, \delta$ and PP cells, which secrete the hormones 
glucagon, insulin and amylin, somatostatin and pancreatic polypeptide, respectively. The bulk of the gland is exocrine, comprising $70-90 \%$ of acinar cells and $5-25 \%$ of duct cells, depending on the species [1-3]. Acini secrete fluid containing $\mathrm{NaCl}$ and a variety of digestive enzymes including active enzymes ( $\alpha$-amylase, lipase, colipase, carboxyl ester lipase, RNAse, DNAse), zymogens (trypsinogen, chymotrypsinogen, procarboxypeptidases A and B, proelastase and proprotease E) and other proteins (e.g. trypsin inhibitor, pancreatitis-associated protein and lithostathine). This enzyme-rich secretion is led through a series of excurrent ducts, which secrete a $\mathrm{NaHCO}_{3}$-rich fluid. The pancreatic juice aids enzymatic breakdown of various macromolecules in the duodenum and together with the bile and duodenal secretions it contributes to neutralization of acid chyme entering the duodenum.

Both endocrine and exocrine cells are regulated by parasympathetic and sympathetic nerves, hormones, autocrine and paracrine mediators as well as nutrients like glucose. The integrated function of the organ is on the one hand due to the contribution to digestive processes in the gastrointestinal tract, thanks to secretion of pancreatic enzymes, and on the other hand due to contribution to regulation of the body and cellular metabolism, thanks to the pancreatic hormones. In the latter process, the prime function is the production of the energy source, ATP. In recent years it has become accepted that ATP and other nucleotides/nucleosides have extracellular roles. They are (1) released from cells; (2) they act extracellularly via specific purinergic receptors as autocrine, paracrine and neural regulators; and (3) they are hydrolysed by various ectoenzymes. The aim of this review is to address the question of whether such "purinergic signalling" is important for regulation of pancreatic endocrine and exocrine functions - both in health and disease. The focus will be on purinergic receptors, which by virtue of a variety in molecular structures, signalling pathways and distribution could regulate many processes in this complex organ.

\section{Endocrine pancreas}

$\beta$ cells

A peculiar feature of $\beta$ cells, and also $\alpha$ cells, is that they use ATP in three processes: (1) as an energy source, (2) as an intracellular second messenger acting on $\mathrm{K}^{+}$channels and (3) as an extracellular regulator. The latter role was discovered quite early in the purinergic era. In the 19601970s it was reported that exogenous ATP stimulated insulin release in various preparations of rat and rabbit pancreas as well as in in vivo experiments performed on man and monkey [4-7]. In 1979 Loubatieres-Mariani et al.
[6] proposed that purinergic receptors control the $\beta$-cell function. Those early studies established that ATP and ADP were potentiators of insulin secretion, which was initiated by glucose entry. Purines (ATP and ADP) were more effective than pyrimidines, and adenosine had an unusual dose-dependent effect on insulin secretion (see below). The following paragraphs will focus on the effects of ATP/ ADP-preferring P2 receptors and adenosine-preferring P1 receptors and extend on the basic model of insulin secretion (Fig. 1).

$P 2$ receptors Purinergic receptors have been studied extensively in in vivo and in vitro preparations of rat, mouse and dog pancreas, as well as on islet preparations of these, and also on the human pancreas and several insulinoma cell lines. In all preparations, except those originating from the mouse pancreas (see below), ATP and ADP induced insulin secretion in the presence of glucose. The identity of purinergic receptors on $\beta$ cells was deduced from studies using pharmacological tools and monitoring effects on, for example, insulin release and intracellular $\mathrm{Ca}^{2+}$ signals. ATP and its analogues (e.g. 2-methylthio ATP, ATP $\gamma \mathrm{S}$ ) induced insulin secretion, but ADP and its analogues $(\alpha, \beta$-methylene $\mathrm{ADP}, \mathrm{ADP} \beta \mathrm{S}, \mathrm{ADP} \gamma \mathrm{S}$ ) were more potent and they required at least slightly stimulating glucose concentrations $(8.3 \mathrm{mM})$ [8-12]. These findings indicated presence of an ADP-preferring receptor, such as the $\mathrm{P}_{2} \mathrm{Y}_{1}$ receptor [13]. Supporting evidence for this receptor is the finding that the $\mathrm{P}_{2} \mathrm{Y}_{1}$ inhibitor MRS2179 successfully eliminated the ADP/ ATP effect on $\beta$ cells. Recent studies concentrated on developing thioester nucleotides specific for $\mathrm{P}_{2} \mathrm{Y}_{1}$ receptors $[11,14,15]$. The molecular evidence for the $\mathrm{P}_{2} \mathrm{Y}_{1}$ receptor was provided by cloning of the receptor from rat and mouse insulinoma cells, i.e. RINm5F and MIN6, respectively [16]. Another $\mathrm{P} 2$ receptor was cloned from the human pancreas; this turned out to be the $\mathrm{P}_{2} \mathrm{Y}_{4}$ receptor $[17,18]$, which may originate from pancreatic ducts as well as from $\beta$ cells (see below).

Although the $\mathrm{P} 2 \mathrm{Y}_{1}$ receptor may be the most important $\mathrm{P} 2 \mathrm{Y}$ receptor in regulating insulin secretion, there is also evidence for other P2Y receptors [19-21], and also P2X receptors [12, 22-24], and indeed the $\mathrm{P}_{2} \mathrm{X}_{4}$ receptor was cloned from rat pancreatic islets [25]. Evidence for P2Xtype receptors was provided by intracellular $\mathrm{Ca}^{2+}$ measurements. For example, in the hamster clonal $\beta$-cell line HIT, ATP stimulated $\mathrm{Ca}^{2+}$ influx rather than $\mathrm{Ca}^{2+}$ store release, indicating receptor-operated channels, which could be P2Xtype receptors [22]. Petit et al. [12] found on rat $\beta$ cells and RIN cells that $\alpha, \beta$-methylene ATP (P2X receptor agonist) had transient effects on insulin release and inhibited $\mathrm{K}^{+}$ efflux, and interestingly this happened even at nonstimulating glucose concentrations. A similar finding was made on human islets with $\alpha, \beta$-methylene ATP and low 


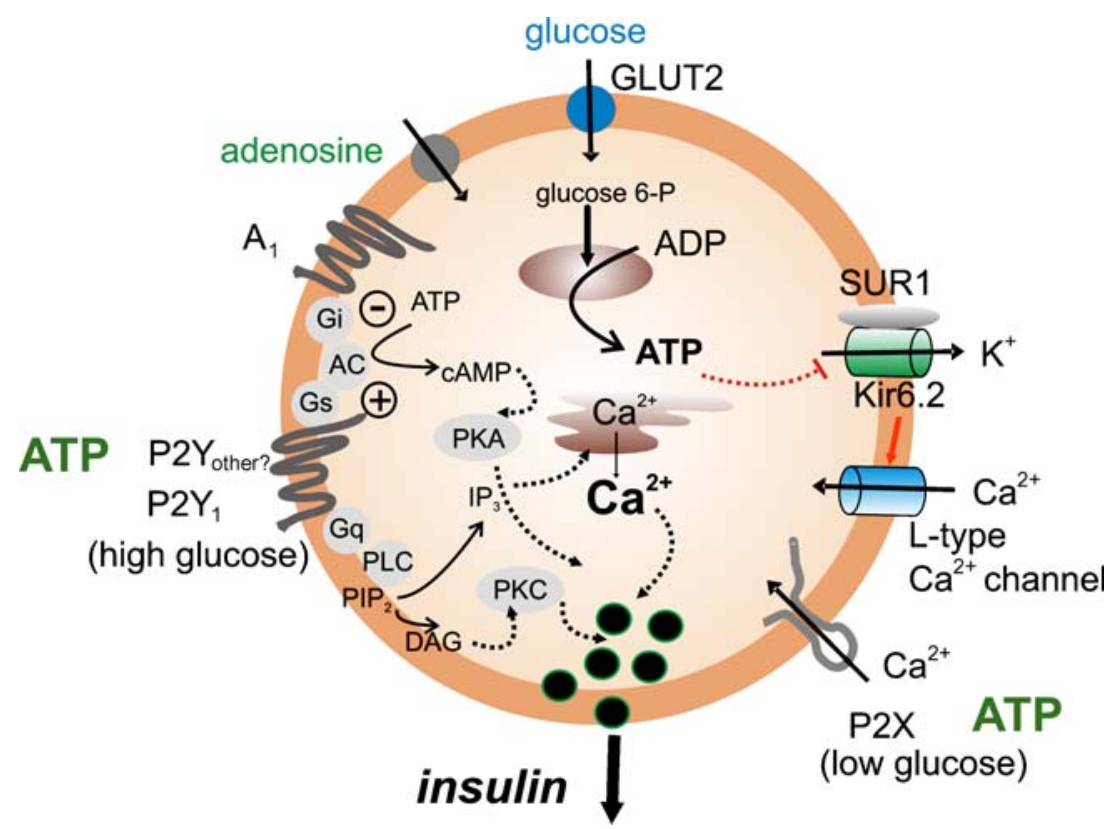

Fig. 1 Role of purinergic receptors in regulation of insulin secretion in the $\beta$ cell. Glucose enters the cell via the facilitative GLUT-2 transporter. Metabolism of glucose leads to production of ATP, which closes the ATP-sensitive channel, $\mathrm{K}_{\text {ATP, }}$ comprising four Kir6.2 and SUR1 subunits. Closure of $\mathrm{K}_{\mathrm{ATP}}$ depolarises the cell membrane and opens voltage-gated L-type $\mathrm{Ca}^{2+}$ channels and $\mathrm{Ca}^{2+}$ action potentials are generated. Increase in the cellular $\mathrm{Ca}^{2+}$ is the triggering event that leads to exocytosis of secretory vesicles containing insulin. Stimulation of $\mathrm{P} 2$ receptors can increase triggering and amplification of

glucose concentrations [10]. Notably, ADP $\beta$ S (P2 $\mathrm{Y}_{1}$ receptor agonist) first became effective when the glucose concentration was increased from 3 to $8.3 \mathrm{mM}$, i.e. from low to slightly stimulating glucose concentrations (Fig. 1) $[10,12]$.

There are only a few immunohistochemical studies on $\mathrm{P} 2$ receptor distribution in the pancreas, and they reveal an unusual pattern [21, 26-28]. $\mathrm{P}_{2} \mathrm{Y}_{1}$ receptors were not detected in rat and mouse islets, as one would have expected from functional studies, but instead they were found on capillaries. Clear immunolocalization of $\mathrm{P} 2 \mathrm{X}_{7}$ receptors was found in $\alpha$ cells and transiently in $\beta$ cells of developing rat pancreas. In early non-obese diabetic mice, $\mathrm{P} 2 \mathrm{X}_{7}$ receptor-labelled cells migrated to the centre of islets, but disappeared at the later stage, and although macrophages and dendritic cells invaded the islets they showed no $\mathrm{P} 2 \mathrm{X}_{7}$ receptor immunoreactivity. Also $\mathrm{P} 2 \mathrm{X}_{1}$ and $\mathrm{P} 2 \mathrm{X}_{4}$ receptors were localised in the islets of adult animals, but they were absent in the neonate animals. $\mathrm{P}_{2} \mathrm{Y}_{4}$ receptor immunoreactivity was detected in $\beta$ cells (and $\alpha$ cells) and staining seemed to increase in the islets of diabetic rats.

Very recently a new report appeared on the molecular characterization of P2 receptors in INS-1 cells [20]. It was shown that INS-1 cells indeed express $\mathrm{P}_{2} \mathrm{Y}_{1}$ receptors. In addition, they also express $\mathrm{P} 2 \mathrm{Y}_{2}, \mathrm{P}_{2} \mathrm{Y}_{4}$ and $\mathrm{P} 2 \mathrm{Y}_{6}$ receptors, signals associated with the glucose effect on insulin secretion. The $\mathrm{P}_{2} \mathrm{Y}_{1}$ receptors increase cellular $\mathrm{Ca}^{2+}$ and activate $\mathrm{PKC}$ pathways. In addition, the $\mathrm{P} 2 \mathrm{Y}_{1}$ or other $\mathrm{P} 2 \mathrm{Y}$ receptors can activate the cyclic AMP pathway. Putative $\mathrm{P} 2 \mathrm{X}$ receptors allow $\mathrm{Ca}^{2+} / \mathrm{Na}^{+}$influx and membrane depolarisation, and thereby they can elicit some insulin secretion even at low glucose concentrations. Adenosine interacts with the $A_{1}$ receptors, which inhibit the cyclic AMP pathways and thereby insulin secretion. At high adenosine concentrations, it is postulated that some adenosine transported into the $\beta$ cell exerts metabolic effects

which stimulate other $\mathrm{Ca}^{2+} / \mathrm{PKC}$ signalling, as well as $\mathrm{P} 2 \mathrm{Y}_{12}$ receptors, which are coupled to $\mathrm{G}_{\mathrm{i}}$ proteins and may have inhibitory function via the cAMP/PKA signalling. Similar molecular characterization of human $\beta$ cells and other islet cells will be necessary for future elucidation of pharmacological and functional profiles.

What intracellular signals elicited by purinergic receptors in $\beta$ cells could potentiate $\mathrm{Ca}^{2+}$-dependent exocytosis of insulin? From studies mostly carried out on the insulinoma cell line RINm5F, we learned that extracellular ATP depolarised $\beta$ cells due to closure of $\mathrm{K}_{\mathrm{ATP}}$, and depolarization elicited $\mathrm{Ca}^{2+}$ action potentials and $\mathrm{Ca}^{2+}$ oscillations $[23,29]$. Intracellular $\mathrm{Ca}^{2+}$ increase is due to (1) activation of PLC, generation of inositol $(1,4,5)$ triphosphate and $\mathrm{Ca}^{2+}$ mobilization from intracellular stores and (2) $\mathrm{Ca}^{2+}$ influx via channels that are not L-type voltage-activated channels, perhaps P2X receptors (Fig. 1) [19, 23, 24, 29-31]. Nevertheless, the ATP-induced insulin release can be somewhat independent of extracellular $\mathrm{Ca}^{2+}[23,29]$. These findings indicate that ATP exerts effect via PLC-dependent and also PLC-independent pathways. Interestingly, when ADP $\beta S$ was used on $\beta$ cells and clonal rat insulinproducing INS-1 cells, cyclic AMP and PKA activation enhanced insulin release [32]. Perhaps parallels could be drawn with new studies on INS-1 cells where glucagon and 
glucagon-like peptide-1 (GLP-1) elicit interdependent cyclic AMP and $\mathrm{Ca}^{2+}$ oscillations [33]. Returning to P2Y receptors, the question is whether one type of receptor, i.e. $\mathrm{P}_{2} \mathrm{Y}_{1}$ receptor, stimulates multiple pathways or whether another type of receptor is also involved, e.g. P2 $\mathrm{Y}_{11}$ receptor, which can signal via different $G$ proteins, $G_{q}$ and $\mathrm{G}_{\mathrm{s}}$ [13]. Taken together, it is well established that P2Y receptors potentiate insulin secretion by a mechanism that involves metabolism of glucose, rise in intracellular $\mathrm{Ca}^{2+}$ and possibly cAMP (Fig. 1). The inhibitory effect on $\mathrm{K}_{\mathrm{ATP}}$ channels is not direct and extracellular, but rather via intracellular events [34].

Let us now consider mouse $\beta$ cells, which seem a little bit peculiar with respect to $\mathrm{P} 2$ receptors and their effect on insulin secretion. In 1989 Petit et al. [9] found that in mouse $\beta$ cells ADP analogues had inhibitory rather than stimulatory effect on insulin. Poulsen et al. [35] verified the inhibitory effect of ATP on insulin secretion and studied cellular effects. Activity of $\mathrm{K}_{\mathrm{ATP}}$ channels (measured as whole-cell $\mathrm{K}^{+}$currents) and exocytosis (measured as capacitance) were inhibited by 2-methylthio ATP $>$ AT$\mathrm{P}>\mathrm{ADP}>\alpha, \beta$-methylene ATP $>\mathrm{UTP}$, thus indicating participation of $\mathrm{P}_{2} \mathrm{Y}_{1}$ receptors and probably also other receptor types. These inhibitory effects on activity $\mathrm{K}_{\mathrm{ATP}}$ channels and exocytosis involved activation of $\mathrm{PLA}_{2}$ and calcineurin, respectively. Since the intracellular $\mathrm{Ca}^{2+}$ signals and currents were intact, inhibitory action of nucleotides on the secretory machinery lay downstream of $\mathrm{Ca}^{2+}$. Similar inhibitory effects of ATP on insulin release were also observed in the mouse $\beta$-cell line MIN6, which has transcripts for $\mathrm{P}_{2} \mathrm{Y}_{4} / \mathrm{P}_{2} \mathrm{Y}_{6}$ receptors [36]. Together, studies to date show that in mouse $\beta$ cells and MIN6 cells, ATP is more potent than ADP in evoking transient $\mathrm{Ca}^{2+}$ spikes [35-37]. In comparison to rat $\beta$ cells and other preparations, the question is whether mouse $\beta$ cells have a different complement of $\mathrm{P} 2$ receptors or whether $\mathrm{P}_{2} \mathrm{Y}_{1}$ receptors have different intracellular coupling to the exocytotic machinery. A recent study on islets isolated from $\mathrm{P}_{2} \mathrm{Y}_{1}-/-$ mice showed that insulin secretion was increased in the presence of high glucose concentrations. In addition, $\mathrm{P}_{2} \mathrm{Y}_{1}$-/- mice exhibited a tendency to glucose intolerance [38]. These findings indicate that $\mathrm{P}_{2} \mathrm{Y}_{1}$ receptors do play some physiological role in glucose homeostasis of the mouse.

Adenosine receptors In 1982 Bacher et al. [39] showed on in situ perfused dog pancreas that the adenosine analogue NECA (adenosine- $5^{\prime} N$-ethylcarboxamide) inhibited insulin release when given in micromolar concentrations, but increased it when given in millimolar concentrations. Similarly, in mouse $\beta$ cells, low adenosine concentrations inhibited glucose-related electrical activity and insulin release and high adenosine concentrations stimulated it
[40]. It is possible that the high-concentration effect was due to transport of adenosine into the cell and subsequent metabolic effects. The inhibitory effect of low-concentration adenosine is exerted via $A_{1}$ receptors $[7,19,40]$, which via $\mathrm{G}_{\mathrm{i}}$ proteins would inhibit adenylate cyclase and thus insulin secretion (Fig. 1). The presence of $A_{1}$ receptor could also explain some observations relating to the dual effect of ATP on insulin secretion. That is, the stimulatory effect at low ATP concentrations is exerted via $\mathrm{P}_{2} \mathrm{Y}_{1}$ and other receptors as discussed above. In addition, ATP at high concentrations can have inhibitory effects, because it is metabolised to adenosine, which via $A_{1}$ receptors would dominate the insulin response [19].

$\alpha$ cells and $\delta$ cells

In dog and rat pancreas adenosine and analogues, e.g. NECA, induced dose-dependent glucagon release from $\alpha$ cells, presumably via $\mathrm{A}_{2}$ receptors [39, 41, 42]. These actions were eliminated by aminophylline and theophylline. Interestingly, Bertrand et al. [43] showed in dog pancreas that 2-methylthio ATP, apart from inducing insulin release, also induced glucagon release. They postulated that since glucagon secretion was delayed with respect to insulin secretion, and since 2-methylthio ATP can be metabolised to adenosine, the effect on glucagon secretion was via adenosine receptors (see Fig. 2). Similarly to $\beta$ cells, also $\alpha$ cells have $\mathrm{K}_{\text {ATP }}$ channels, which are more sensitive to ATP, and they play a major role in electrical activity and secretory processes $[44,45]$.

Regarding $\delta$ cells, there are only a few studies available. In low glucose concentrations ( $4.2 \mathrm{mM}), \alpha, \beta$-methylene ADP had no effect on insulin or glucagon secretion, but it induced somatostatin secretion from $\delta$ cells-indicating the presence of P2 receptors [43]. A similar finding was made in perfused dog pancreas, where a more stable analogue ADP $\beta S$ induced release of somatostatin, but not of glucagon [46].

\section{Source of ATP}

Pancreatic islets are innervated by both the parasympathetic and sympathetic nerves. From studies of other systems it is known that ATP is released from presynaptic terminals containing other transmitters such as: (1) acetylcholine and vasoactive intestinal peptide (VIP) in some parasympathetic nerves, (2) with noradrenaline and neuropeptide $\mathrm{Y}$ in sympathetic nerves and (3) with NO and VIP in enteric inhibitory nerves (Fig. 2) [47-49]. In the pancreas, ATP and acetylcholine have synergistic effects on insulin release [50].

Another source of ATP and nucleotides are insulincontaining granules of $\beta$ cells [51-54]. Obermuller et al. [55] showed that adenine nucleotides are released with a 
Fig. 2 Sources and roles of nucleotides in a pancreatic islet. Nucleotides are released from nerves or from insulin-containing granules. ATP/ADP can autoregulate insulin release and/or affect coupling between $\beta$ cells. Extracellular hydrolysis by ectoenzymes leads to production of adenosine that could on the one hand down-regulate insulin secretion from $\beta$ cells, and on the other hand it could stimulate glucagon release in $\alpha$ cells. High glucose inhibits glucagon release in $\alpha$ cells. The graph shows the theoretical oscillations in insulin and glucagon levels in the presence of high glucose concentrations

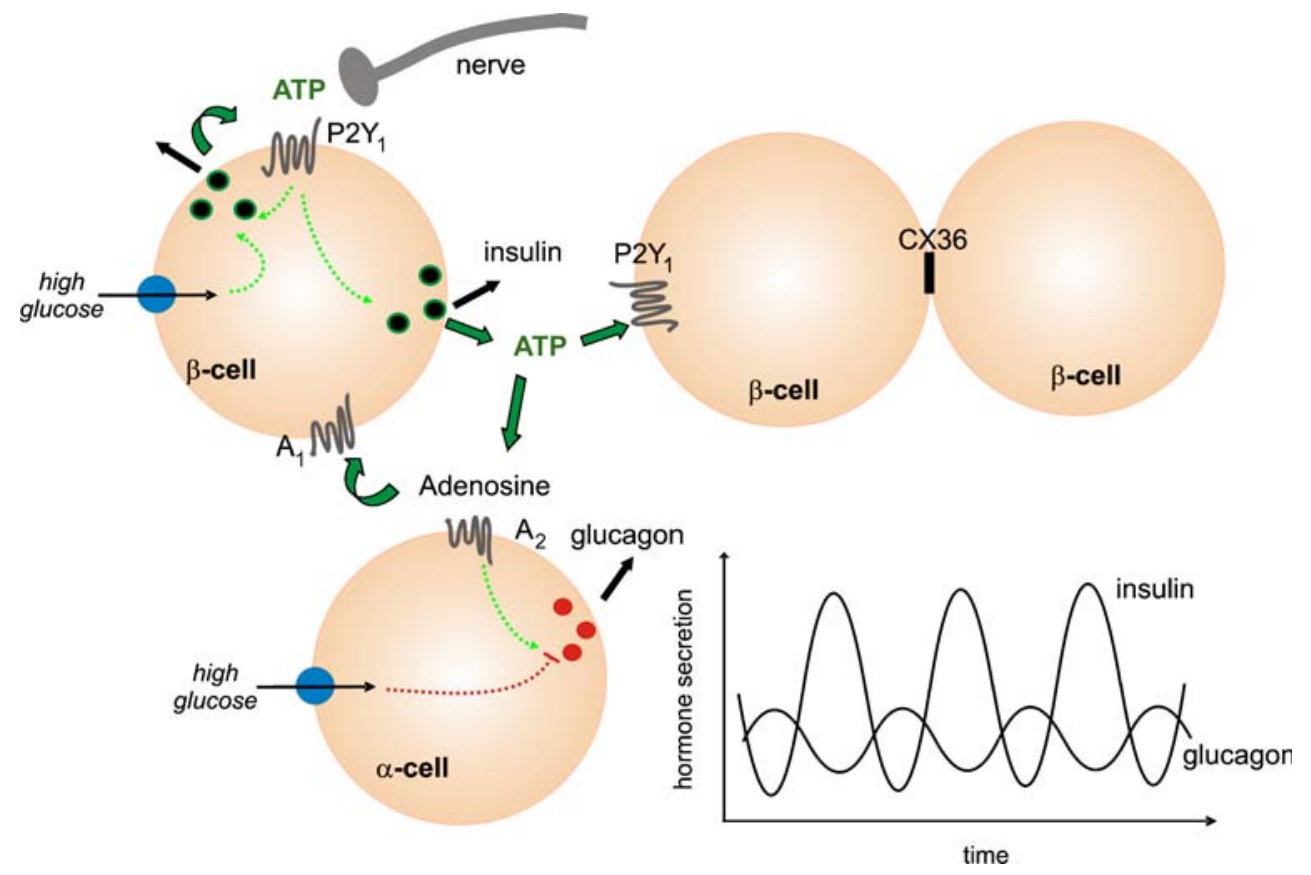

very short delay after stimulation, while peptides (insulin) are released later. Using a biosensor technique, Hazama et al. [52] detected ATP release on the cell surface of $\beta$ cells and estimated the concentration to be about $25 \mu \mathrm{M}$. Importantly, glucose alone can cause ATP release, indicating that there is autocrine/paracrine signalling, which could promote insulin release (Fig. 2). Thus, one role for released nucleotides could be potentiation of the glucose effect and perhaps this could explain the biphasic insulin secretion [7] or the oscillatory release of insulin (see below). Another role for released nucleotides could be regulation of exocrine function (see the "Exocrine" section).

Islet as a whole-oscillations and possible role of nucleotides

High glucose induces pulsatile insulin release. This occurs in many species in vivo, in the isolated pancreas and in single islets (see [56]). Insulin oscillations are accompanied by $\mathrm{Ca}^{2+}$ oscillations and can be uncoupled in some circumstances, e.g. in $o b / o b$ mice, in old animals and with hyperstimulation [57, 58]. Moreover, in type 2 diabetes, the pulsatile pattern of insulin release is impaired [56]. Mechanisms governing oscillations are unclear. A neurogenic component is believed to play a role, but a recent study showed that also coupling between $\beta$ cells must be important. Loss of connexin, CX36, changes $\beta$-cell coupling and islet synchronization of glucose-induced $\mathrm{Ca}^{2+}$ and insulin oscillations [59]. In addition, recent studies indicated that also exogenous and endogenous nucleotides may play a role in this rhythmicity. Exogenous ATP (or ADP and 2-methylthio ATP) elicits oscillations in the membrane potential, intracellular $\mathrm{Ca}^{2+}$ and PLC [30, 60, 61]. Interestingly, in rat $\beta$ cells the $P 2 Y_{1}$ antagonist MRS2179 inhibited glucose-induced insulin oscillations measured in the portal vein, but strangely it did not inhibit $\mathrm{Ca}^{2+}$ oscillations [62].

Glucose is a stimulator of insulin release, but it usually suppresses release of glucagon from $\alpha$ cells in intact islets. Thus, in contrast to $\beta$ cells, glucagon-secreting $\alpha$ cells presented asynchronous $\mathrm{Ca}^{2+}$ oscillatory patterns in response to low glucose concentrations, and this pattern was suppressed in high glucose concentrations [63]. In a recent study on rat preparations, where high frequency sampling of venous effluents was used, it was shown that high glucose induced insulin release and also glucagon release about $180^{\circ}$ out of phase, and this was sensitive to the MRS2179 inhibitor [64]. One possible interpretation is that high glucose induced release of insulin and nucleotides, which on the one hand potentiated the effect of glucose on $\beta$ cells. On the other hand, the hydrolytic product adenosine could then via $A_{1}$ receptors on $\beta$ cells downregulate release of insulin, and on $\mathrm{A}_{2}$ receptors of $\alpha$ cells it could stimulate release of glucagon (see model in Fig. 2). Nevertheless, for a physiologically relevant situation, the total amounts of cyclically released insulin and glucagon would have to be coordinated depending on the glucose level: high glucose and ATP should favour insulin secretion; and low glucose and adenosine would favour glucagon release. 
Therapeutic potentials for improving insulin secretion

Many drugs can increase insulin secretion in vitro, but only some have a therapeutic potential for treatment of noninsulin-dependent diabetes. The most frequently used drugs to date are sulphonylureas and glinides, which decrease the open probability of $\mathrm{K}_{\mathrm{ATP}}$ channels, and result in depolarization of the cell membrane, and the increase in cell $\mathrm{Ca}^{2+}$ leads to insulin release [61, 65-67]. The action of these drugs is independent of plasma glucose concentrations and therefore it may be difficult to achieve glycaemic control, i.e. they can lead to hypoglycaemia. Since $\mathrm{P}_{2} \mathrm{Y}_{1}$ receptor agonists amplify insulin release in the presence of stimulating glucose concentrations, they may potentially reduce the risk of hypoglycaemia. Intravenously and orally administered ADP $\beta S$ was a potent insulin secretagogue and improved glucose tolerance in the in vivo rat and dog pancreas $[46,68]$. P2Y receptor agonists also amplified secretion of insulin on an in vitro pancreas preparation from Zucker diabetic rats [69]. In human islet preparations, P2Y receptor agonists were also successful in inducing glucosedependent insulin secretion [70]. Nevertheless, it is important to consider possible effects of P2 agonists on blood vessels [71] and also on the exocrine pancreas (see below). Recent efforts have led to the development of $\mathrm{C} 2$ substituted ATP analogues [thioester nucleotides such as 2-thioester 5'-O-(1-thiotriphosphate) adenosine derivatives], which would be specific for $\mathrm{P}_{2} \mathrm{Y}_{1}$ receptors on $\beta$ cells. Fischer and collaborators found some very effective analogues regarding insulin release (potent in the nanomolar range) and stable regarding degradation by NTPDase, but unfortunately these also had pronounced vasodilatory effects in the rat pancreas $[14,15]$. Most recently, a new generation of 2-substituted $5{ }^{\prime}-O$-(1-boranotriphosphate) adenosine analogues was developed. One of these, 2-methylthio-ATP- $\alpha$-B (A isomer) was able to elicit glucose-dependent insulin secretion with high efficacy in rats, and it had minimal effects on pancreatic vascular resistance [11]. Thus, this analogue is a good candidate for future therapeutic developments.

Another approach to increase insulin secretion could be to inhibit $A_{1}$ receptors on $\beta$ cells. Bacher et al. [39] showed that the methylxanthine compound aminophylline attenuated the action of adenosine in the dog pancreas. On human subjects one study showed that aminophylline had no influence on basal insulin secretion, it augmented glucoseinduced insulin secretion in healthy subjects, but not in patients with type 2 diabetes [72]. In contrast, another study on a small group of type 2 diabetic patients showed that aminophylline stimulated insulin secretion [73]. Since methylxanthines have many other molecular and systemic effects, future efforts are needed to find $\beta$-cell-specific compounds. Apart from the endocrine pancreas, adenosine receptors in other tissues are also targets for diabetes treatment, e.g. stimulation of $\mathrm{A}_{1}$ receptors in adipocytes inhibits lipolysis and increases glucose metabolism, and inhibition of $\mathrm{A}_{2 \mathrm{~B}}$ receptors in hepatocytes would control glucose production [74].

\section{Exocrine pancreas}

\section{Pancreatic acini}

Pancreatic acini are well studied with respect to mechanism and regulation of enzyme secretion, intracellular $\mathrm{Ca}^{2+}$ signalling and ion transporters involved in fluid secretion. Compared to acini of other exocrine glands, knowledge regarding the role of purinergic receptors in pancreatic acini is limited $[75,76]$. Reverse transcriptase polymerase chain reaction (RT-PCR) analysis on single acini from the rat pancreas revealed that they contain transcripts for $\mathrm{P} 2 \mathrm{X}_{1}$, $\mathrm{P}_{2} \mathrm{X}_{4}, \mathrm{P}_{2} \mathrm{Y}_{2}$ and $\mathrm{P}_{2} \mathrm{Y}_{4}$ receptors [77]. Interestingly, no transcript for $\mathrm{P} 2 \mathrm{X}_{7}$ receptors was found, although these receptors are expressed in ducts (see below) and also in acini of other exocrine glands [78-81]. Clearly, P2X 7 receptors, which can form lytic pores under some conditions, would be dangerous in pancreatic acini filled with digestive enzymes. Their untimely activation and release could initiate autodigestive processes, such as occurs in pancreatitis. In this light, it will be important to establish whether human pancreatic acini also lack $\mathrm{P} 2 \mathrm{X}_{7}$ receptors.

Functional studies using intracellular $\mathrm{Ca}^{2+}$ measurements and measurement of organic anion uptake on single cells within acini revealed than only about $10-20 \%$ of cells responded to extracellular ATP or UTP [77, 82]. Thus, it seems that there are only a few cells within an acinus or a few acini that have functional P2 receptors, and that P2 receptor-induced effects remain contained within single cells and thereby may not have significant effect on secretion processes as a whole. If this assumption holds, it would be tempting to postulate that scarcity of functional P2 receptors in acini is advantageous for the tissue that releases significant amounts of ATP and is prone to autodigestion (see below). However, it cannot be excluded that receptors are not accessible or are down-regulated in the particular rat gland preparation, or that ATP does not reach the receptor due to efficient hydrolytic enzymes (see below). In comparison, about $90 \%$ of acini prepared from other exocrine glands (e.g. salivary and lachrymal glands) using similar methods respond to ATP, although there is a functional heterogeneity in $\mathrm{P}_{2} \mathrm{X}_{4}, \mathrm{P}_{2} \mathrm{Y}_{2}$ and $\mathrm{P}_{2} \mathrm{Y}_{1}$ receptors, and these acini also express $\mathrm{P} 2 \mathrm{X}_{7}$ receptors $[78,79$, $81,83-88$ ]. It is also established in exocrine gland acini that distribution and function of some $\mathrm{P} 2$ receptor is influenced by the developmental state, innervation and duration of cell culture [78, 87-90]. Thus, for pancreatic acini, the possible 
role of $\mathrm{P} 2$ receptors in short-term and long-term effects on secretory and other processes needs further investigation.

Pancreatic ducts-native tissue

P2 receptors In contrast to pancreatic acini, pancreatic ducts exhibit functional P2 receptors. Detailed analyses of molecular identity and function of P2 receptors were carried out on the rat (and guinea pig) pancreas and therefore this will be the starting and reference point for other numerous studies on human duct lines. In single pancreatic ducts microdissected from the rat pancreas, ATP had a concentration-dependent effect on the membrane potential and it stimulated both $\mathrm{Ca}^{2+}$ release and $\mathrm{Ca}^{2+}$ influx with the following potency UTP $\geq$ ATP $>2$-methylthio-ATP $>\alpha, \beta$ methylene-ATP»adenosine [91-94]. BzATP, which is an agonist for $\mathrm{P}_{2} \mathrm{X}_{7}$ and also other $\mathrm{P} 2 \mathrm{X}$ receptors [95], induced fully reversible $\mathrm{Ca}^{2+}$ and $\mathrm{Na}^{+}$influx. RT-PCR analysis revealed that rat pancreatic ducts have transcripts for $\mathrm{P}_{2} \mathrm{Y}_{2}, \mathrm{P}_{2} \mathrm{Y}_{4}, \mathrm{P} 2 \mathrm{X}_{4}$ and $\mathrm{P} 2 \mathrm{X}_{7}$ receptors [94], which agrees with studies of $\mathrm{Ca}^{2+}$ transients and other functional assays discussed below. Luo and Muallem [96] found a greater variety of receptors on rat pancreatic tissue, probably reflecting differences in tissue preparation. Using immunohistochemistry, Coutinho-Silva et al. [21, 26] detected $\mathrm{P}_{2} \mathrm{Y}_{2}$ receptors on pancreatic ducts, and $\mathrm{P} 2 \mathrm{Y}_{1}$ on neonate ducts, but with given antibodies no $\mathrm{P} 2 \mathrm{X}_{4}$ or $\mathrm{P} 2 \mathrm{X}_{7}$ receptors were detected on the exocrine pancreas, but rather on pancreatic islets. Further experimental approaches are needed to resolve the discrepancy between molecular and functional identity and immunoidentification of the P2 receptors.

Before analysing the possible role of $\mathrm{P} 2$ receptors in duct function, let us summarise known secretory and regulatory mechanisms in pancreatic ducts (Fig. 3a). The classic secretagogues secretin and acetylcholine stimulate ductal secretion by primary opening of CFTR (the cystic fibrosis transmembrane regulator) $\mathrm{Cl}^{-}$channel, regulated by the cAMP pathway, or opening of $\mathrm{Ca}^{2+}$-activated $\mathrm{Cl}^{-}$channels. Parallel activity of various $\mathrm{H}^{+}$and $\mathrm{HCO}_{3}^{-}$transporters ensures transport of $\mathrm{HCO}_{3}^{-}$into duct lumen [97, 98]. The driving force for anion transport is kept by opened $\mathrm{K}^{+}$ channels [91, 99-102]. Interestingly, in rat pancreatic ducts UTP (which activates rat $\mathrm{P}_{2} \mathrm{Y}_{2}$ and $\mathrm{P}_{2} \mathrm{Y}_{4}$ receptors with about equal efficiency) decreased the whole-cell $\mathrm{K}^{+}$ conductance and no effect on the $\mathrm{Cl}^{-}$conductance could be detected [94]. Thus, it was predicted that these receptors would down-regulate ductal secretion (Fig. 3b). This was in fact found in isolated guinea pig pancreatic ducts, where the basolateral application of UTP decreased secretion [103]. A similar effect of UTP on secretory processes was also detected in polarised Capan-1 cells, which are epithelial cells derived from pancreatic adenocarcinoma [104]. RT-
PCR analysis of the single rat ducts revealed that they express $\mathrm{Ca}^{2+}$-activated $\mathrm{K}^{+}$channels of the intermediate conductance (IK also known as SLO, Maxi $\mathrm{K}$ and KCNMA1) and big conductance (BK also known as SK4, KCNN4) [105]. Human IK or BK channels were coexpressed with $h \mathrm{P}_{2} \mathrm{Y}_{2}$ or $h \mathrm{P}_{2} \mathrm{Y}_{4}$ receptors in Xenopus oocytes and cell currents were measured. Notably, $\mathrm{P} 2 \mathrm{Y}_{2}$ receptors inhibited $\mathrm{BK}$ channels; the other receptor/channel combinations, such as $\mathrm{P}_{2} \mathrm{Y}_{2}$ and IK, $\mathrm{P}_{2} \mathrm{Y}_{4}$ and $\mathrm{BK}$ or IK, were stimulatory. Thus, most likely on the basolateral membrane of pancreatic ducts, the $\mathrm{P}_{2} \mathrm{Y}_{2}$ receptor-mediated effect on BK channels dominates the whole-cell conductance and $\mathrm{K}^{+}$channel inhibition down-regulates secretion (Fig. 3b). The cellular signalling between the $\mathrm{P}_{2} \mathrm{Y}_{2}$ receptor and $\mathrm{BK}$ is yet to be established, and recent discoveries of $\mathrm{P}_{2} \mathrm{Y}_{2}$ receptor interactions with various intracellular signalling pathways offer a number of possibilities $[106,107]$. In theory, the function of this $\mathrm{P}_{2} \mathrm{Y}_{2}$ receptor to $\mathrm{BK}$ interaction would be the "brake" or "control" point in regulation of secretion in the ductal system, perhaps sensing and preventing distension of the duct. Other mediators, such as substance $\mathrm{P}$ and atrial natriuretic factor, have been ascribed similar protective roles since they inhibit duct secretion $[108,109]$.

In contrast to $\mathrm{BK}$ channels, IK channel regulation by $\mathrm{P}_{2} \mathrm{Y}_{4}$ or even $\mathrm{P} 2 \mathrm{Y}_{2}$ receptors is stimulatory, as would be required for secretory processes [105]. Therefore, localization of these channels and receptors and conditions that will favour secretory events need to be elucidated. Since exocrine glands, including the pancreas, secrete fluid where $\mathrm{K}^{+}$is higher than in plasma, it is predicted that up to about $20 \%$ of the total cellular $\mathrm{K}^{+}$conductance would increase the secretory rate [110]. In pancreatic ducts, the circuit analysis shows that the luminal $\mathrm{K}^{+}$conductance contributes about $10 \%$ to the total cell $\mathrm{K}^{+}$conductance (Fig. 3b) [99].

Let us turn to the $\mathrm{P} 2 \mathrm{X}$ receptors in pancreatic ducts. BzATP had effects on $\mathrm{Ca}^{2+}$ influx and membrane voltage/ current that could be ascribed to $\mathrm{P} 2 \mathrm{X}_{7}$ or possibly $\mathrm{P} 2 \mathrm{X}_{4}$ receptors, which were detected functionally on the luminal membrane $[94,96]$. It was not possible to detect whether BzATP would also open $\mathrm{Cl}^{-}$channels, or stimulate $\mathrm{H}^{+} / \mathrm{HCO}_{3}^{-}$transport [111]. Thus, if $\mathrm{P} 2 \mathrm{X}_{7}$ receptors, or $\mathrm{P}_{2} \mathrm{X}_{4}$ receptors, have an effect on secretion, it may be by means of up-regulating secretion rather than initiating it. The intracellular mechanisms stimulated by P2X receptors in pancreatic ducts are unknown, but they may involve $\mathrm{Ca}^{2+}$ or $\mathrm{Na}^{+}$influx and an independent activation of mitogenactivated protein kinases, ERK1/2 [112]. Interestingly, in guinea pig pancreatic ducts that were cultured overnight injection of ATP into the lumen (or UTP) increased secretion [103]. Possibly, this could be due to stimulation of $\mathrm{P}_{2} \mathrm{X}_{7}$ receptors, or other receptors such as $\mathrm{P}_{2} \mathrm{Y}_{2}, \mathrm{P}_{2} \mathrm{Y}_{4}$ or adenosine receptors. Taken together, it is not known whether 


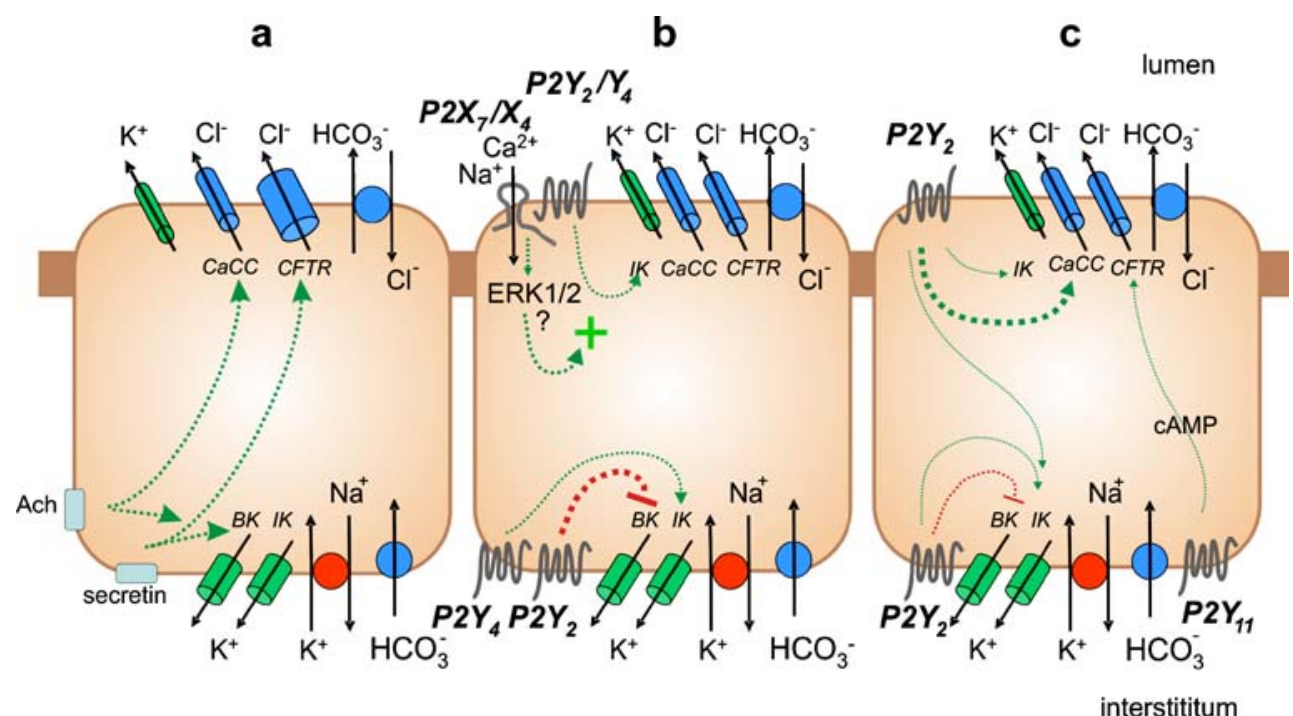

Fig. 3 Purinergic receptors and ion transport in pancreatic ducts. a The basic working model for pancreatic duct secretion elicited by secretin or acetylcholine. The primary events are: opening of CFTR or $\mathrm{Ca}^{2+}$-activated $\mathrm{Cl}^{-}$channels and opening of $\mathrm{K}^{+}$channels that keep the driving force on the secretion. The basolateral membrane transporters, such as $\mathrm{NBC}$ or $\mathrm{NHE}$ (shown as a $\mathrm{HCO}_{3}^{-}$import for simplicity), and activity of intracellular carbonic anhydrase lead to accumulation of intracellular $\mathrm{HCO}_{3}^{-}$. Exchange of $\mathrm{HCO}_{3}^{-} / \mathrm{Cl}^{-}$results in secretion of $\mathrm{HCO}_{3}^{-}$into the lumen, and this is accompanied by $\mathrm{Na}^{+}$and water transport giving rise to $\mathrm{NaHCO}_{3}$-containing secretion. b P2 receptors in native rat pancreatic ducts. $\mathrm{P} 2 \mathrm{Y}_{2}$ receptors have the dominant effect on BK channels, most likely on the basolateral membrane. Some conclusions regarding BK inhibition and IK activation are also in agreement with data on guinea pig ducts and human cell lines. c P2Y receptors on human and canine duct epithelium. The size of lines and arrows indicates the degree of $\mathrm{P} 2 \mathrm{Y}$ receptor and ion channels stimulation most commonly observed. The $\mathrm{P}_{2} \mathrm{Y}_{2}$ receptor inhibits BK channels, as indicated by the dash the target effect of putative $\mathrm{P} 2 \mathrm{X}_{7}$ receptors are ion transporters involved in secretion, as may be the case for other exocrine glands [75], or whether effects are long term, involving regulation of cell proliferation or cell death, as described for some cells $[95,113]$. The Raf-MEK-ERK signalling cascade plays a crucial role in the regulation of apoptosis, proliferation and metastasis of pancreatic cancer [114]. We already know that other agonists, such as neurotensin and EGF, promote DNA synthesis in pancreatic cancer cells (Panc-1) via ERK activation $[115,116]$.

One of the well described effects of $\mathrm{P}_{2} \mathrm{X}_{7}$ receptors is their ability to form or mediate formation of pores, which would allow permeation of large molecules and eventually cause cell lysis $[95,113]$. One of the events precipitating pore formation experimentally is the use of $\mathrm{Ca}^{2+}$ - and $\mathrm{Mg}^{2+}$-free solutions. Pancreatic juice normally has free $\mathrm{Ca}^{2+}$ concentrations varying between 0.1 and $1 \mathrm{mM}$. Thus, in a physiological situation pore formation would not be expected on this basis. Recently, other regulators of $\mathrm{P} 2 \mathrm{X}_{7}$ receptors have been proposed. The microbial peptide LL37, from the family of cathelicidins, could also activate $\mathrm{P}_{2} \mathrm{X}_{7}$ receptors [117]. Although LL37 is found in salivary glands [118] and its role in $\mathrm{P}_{2} \mathrm{X}_{7}$ receptor stimulation has been discussed $[119,120]$, there are no reports of cathelicidins in the pancreas. It has also been proposed that extracellular $\mathrm{Cl}^{-}$could regulate the $\mathrm{P} 2 \mathrm{X}_{7}$ receptor in parotid gland ducts $[119,121]$. Since pancreatic ducts transport $\mathrm{Cl}^{-}$and pancreatic secretion varies in concentration of $\mathrm{Cl}^{-}$, the effect of extracellular $\mathrm{Cl}^{-}$on luminal $\mathrm{P} 2 \mathrm{X}_{7}$ it is an interesting possibility.

The $\mathrm{P} 2 \mathrm{X}_{4}$ receptors are widely expressed in all exocrine glands - pancreatic acini and ducts, parotid and submandibular acini and ducts [75]. Usually, the function of $\mathrm{P}_{2} \mathrm{X}_{4}$ receptors has been difficult to separate from $\mathrm{P}_{2} \mathrm{X}_{7}$ receptors, except for a recent study on human parotid acini, where it was shown that cAMP potentiates ATP-evoked $\mathrm{Ca}^{2+}$ signalling via $\mathrm{P} 2 \mathrm{X}_{4}$ receptors [81]. Overall, stimulation of $\mathrm{P} 2 \mathrm{X}$ receptors in other exocrine glands allows $\mathrm{Na}^{+} /$ $\mathrm{Ca}^{2+}$ influx and stimulation of $\mathrm{K}^{+}$channels, $\mathrm{Na}^{+} / \mathrm{H}^{+}$ exchange, $\mathrm{Na}^{+}-\mathrm{K}^{+}-\mathrm{Cl}^{-}$cotransport, causes volume changes and stimulates amylase release $[75,76]$. Therefore, some $\mathrm{P} 2 \mathrm{X}$ receptors could be involved in genuine secretory events in the exocrine glands.

Pancreatic ducts—cultured tissue

Numerous studies have been carried out on human pancreatic adenocarcinoma epithelial cell lines-Panc-1, Capan-1, HPAF and CFPAC-1 cells. Only the first two lines express functional CFTR; HPAF cells have low levels of CFTR and CFPAC-1 cells are derived from a CF patient with deletion of Phe-508 in CFTR. CFPAC-1 cells have been of special 
interest because it is predicted that $\mathrm{P} 2$ receptor stimulation could activate $\mathrm{Ca}^{2+}$-activated $\mathrm{Cl}^{-}$channels as an alternative secretory pathway to the defective CFTR. Hence, the agonists commonly used are ATP and UTP, and the results are interpreted in connection with the $\mathrm{P} 2 \mathrm{Y}_{2}$ receptor.

In CFPAC-1 cells, ATP or UTP stimulation increased cellular $\mathrm{Ca}^{2+}$ and it increased $\mathrm{Cl}^{-}$efflux measured as halide efflux, short-circuit or whole-cell current, or as a decrease in intracellular $\mathrm{Cl}^{-}$activity (Fig. 3c) [122-126]. In addition, ATP/UTP also stimulated $\mathrm{HCO}_{3}^{-}$efflux, associated with $\mathrm{Cl}^{-} / \mathrm{HCO}_{3}^{-}$exchange and monitored by intracellular $\mathrm{pH}$ measurements $[125,126]$. In some studies it was reported that nucleotides also stimulated $\mathrm{K}^{+}$currents $[122,125]$. In HPAF cells, which have relatively low expression of CFTR, luminal ATP stimulated $\mathrm{Ca}^{2+}$-activated $\mathrm{Cl}^{-}$transport, and furthermore transepithelial short-circuit current was dependent on $\mathrm{K}^{+}$channel activity [102]. Functionally, the $\mathrm{K}^{+}$ channels are seen as clotrimazole-sensitive $\mathrm{Ca}^{2+}$-activated $\mathrm{K}^{+}$channels and their molecular identity corresponds most likely to IK. Interestingly, this cell line lacks $\mathrm{Ba}^{2+}$ sensitivity indicating an absence of BK channels, which are expressed in native duct cells [105]. In most studies on cultured cells, cells were grown on coverslips and nucleotides were added to the apical side. However, in a few studies where nucleotides could be added to either the apical/luminal side as opposed to the basolateral/serosal side, they had a more pronounced effect from the apical side [102, 124, 126]. In two studies nucleotides had the following order of efficacy on stimulation of $\mathrm{Cl}^{-}$transport: $\mathrm{UTP} \approx \mathrm{ATP}>\mathrm{ADP} \gg \alpha, \beta$-methylene ATP, $\beta, \gamma$-methylene ATP, 2-methylene ATP [124, 127]. These data indicate the presence of UTP-preferring receptors, such as $\mathrm{P}_{2} \mathrm{Y}_{2}$ or perhaps $\mathrm{P}_{4} \mathrm{Y}_{4}$ [13]. Despite the relevant effects of ATP/ UTP on $\mathrm{Cl}^{-}, \mathrm{HCO}_{3}^{-}$and $\mathrm{K}^{+}$transport described above, the effects are very short lasting - in the order of seconds to minutes. This may be difficult to reconcile with sustained ductal secretion, which should last minutes to hours.

In several studies, CFPAC-1 cells were compared with either cells with functional CFTR, such as Panc-1 or Capan-1 cells, or with CFTR-transfected CFPAC-1 cells. Nucleotides had a similar order of efficacy in stimulating $\mathrm{Cl}^{-}$efflux from both CFPAC-1 cells and CFTR-corrected CFPAC-1 cells, indicating that $\mathrm{P} 2$ receptor expression was not altered [127]. In Panc-1 cells, ATP had a negligible effect on $\mathrm{Cl}^{-} / \mathrm{HCO}_{3}^{-}$exchange, while it stimulated $\mathrm{Cl}^{-} / \mathrm{HCO}_{3}^{-}$exchange in CFPAC-1 cells [125]. In another study, ATP induced $\mathrm{Cl}^{-}$efflux in both Capan-1 and CFPAC-1 cells; ATP increased $\mathrm{Cl}^{-} / \mathrm{HCO}_{3}^{-}$exchange in Capan-1 cells but in CFPAC- 1 cells $\mathrm{Cl}^{-} / \mathrm{HCO}_{3}^{-}$exchange was low until the cells were corrected with transfected CFTR [126]. Therefore, it is postulated that P2 receptors could be used to restore some $\mathrm{HCO}_{3}^{-}$secretion, but this would not be fully effective until CFTR is also expressed.
Capan-1 cells express functional CFTR and receptors and transporters perhaps closest to a "normal" human duct epithelium. In polarised monolayers, ATP and UTP applied luminally stimulated $\mathrm{HCO}_{3}^{-}$secretion (measured as decrease in $\mathrm{pH}_{\mathrm{i}}$ ), while applied basolaterally they inhibited $\mathrm{HCO}_{3}^{-}$secretion [104]. This is in agreement with studies on rat and guinea pig pancreatic ducts (see above). RT-PCR analysis indicates that this epithelium has transcripts for the following receptors: $\mathrm{P} 2 \mathrm{Y}_{1}, \mathrm{P}_{2} \mathrm{Y}_{2}, \mathrm{P} 2 \mathrm{Y}_{4}$ and $\mathrm{P} 2 \mathrm{Y}_{6}$ and for $\mathrm{P} 2 \mathrm{X}_{1}, \mathrm{P} 2 \mathrm{X}_{4}$ and $\mathrm{P} 2 \mathrm{X}_{5}$, but not $\mathrm{P} 2 \mathrm{X}_{7}$. A recent study on the human pancreas reveals that there are transcripts for $\mathrm{P} 2 \mathrm{X}_{7}$ receptors in the tissue [128], although immunohistochemically receptors could not be localised to exocrine tissue [21]. Nevertheless, our RT-PCR analysis on various human duct cell lines indicates that they have a large repertoire of $\mathrm{P} 2$ receptors, including the $\mathrm{P} 2 \mathrm{X}_{7}$ receptor (unpublished data).

Human duct cell lines have some characteristics of large/ main ducts, and in addition to ion transport they can also secrete mucins. ATP induced mucin secretion in cell lines expressing functional CFTR: Capan-1 cells, CFTR-corrected CFPAC-1 cells, but not in CFPAC-1 cells [129]. It seems that receptors other than $\mathrm{P}_{2} \mathrm{Y}_{2}$ (or $\mathrm{P} 2 \mathrm{Y}_{4}$ ) are involved in mucin secretion as the sequence of efficacy was different to that for ion transport, i.e. ATP $>$ ADP $>$ AMP $>$ adenosine $>$ UTP, and there was little dependence on extracellular $\mathrm{Ca}^{2+}$. Similarly, in cultured canine main duct epithelium mucin secretion was stimulated by ATP by both $\mathrm{Ca}^{2+}$ - and cAMP-dependent pathways [130, 131]. In contrast to ion transport, the ATP effect on mucin secretion was long lasting and seen over $30 \mathrm{~min}$.

Cultured tissue from the canine main ducts was also used for ion transport studies. Although the main duct is a high electrical resistance epithelium compared to low resistance smaller ducts, it nevertheless has a secretory phenotype. Efflux of ${ }^{125} \mathrm{I}^{-}$was stimulated by ATP, UTP, ATP $\gamma \mathrm{S}>\beta, \gamma-$ methylene ATP 》 adenosine and ATP stimulated ${ }^{86} \mathrm{Rb}^{+}$ efflux [132]. Using short-circuit measurements on polarised epithelium, it was shown that both luminal and serosal addition of UTP activated above $\mathrm{Cl}^{-}$and $\mathrm{K}^{+}$conductances, suggesting that $\mathrm{P} 2 \mathrm{Y}_{2}$ receptors are expressed on both sides of the epithelium. Low concentrations of UTP caused $\mathrm{Ca}^{2+}$ oscillation and synchronous activity of $\mathrm{K}^{+}$currents, presumed to be IK channels, and $\mathrm{pH}_{\mathrm{i}}$ measurements indicated $\mathrm{HCO}_{3}^{-}$secretion [131]. This finding supports conclusions drawn from studies on rat and human $\mathrm{P} 2 \mathrm{Y}_{2}$ receptors and IK channels [94, 105]. In addition to $\mathrm{P} 2 \mathrm{Y}_{2}$ receptors, there are also $\mathrm{P} 2 \mathrm{Y}_{11}$ receptors on the basolateral membrane of canine epithelium that activate large $\mathrm{Ca}^{2+}$. independent $\mathrm{Cl}^{-}$conductance and cAMP increases (see Fig. 3c) [133].

Taken together studies on cultured duct epithelia indicate that $\mathrm{ATP} / \mathrm{UTP}$, possibly via $\mathrm{P}_{2} \mathrm{Y}_{2}$ receptors, stimulate ion 
transport and signalling pathways, which would be consistent with secretory processes. However, several issues still need to be resolved. First, the ATP/UTP effects on membrane $\mathrm{Cl}^{-}$and $\mathrm{K}^{+}$channels are transient- thus the question is whether full secretion could be supported. Second, molecular identity, pharmacology and immunolocalization of P2 (and adenosine) receptors needs to be resolved. Third, it is not clear why presumed $\mathrm{P}_{2} \mathrm{Y}_{2}$ receptors behave differently in human and canine duct epithelia compared to rat, guinea pig ducts and expression system in oocytes (i.e. stimulation of $\mathrm{Cl}^{-}$channels vs inhibition of BK channels). Possibly, effects of $\mathrm{P}_{2} \mathrm{Y}_{2}$ or $\mathrm{P}_{2} \mathrm{Y}_{4}$ receptors on $\mathrm{Cl}^{-}$ channels and IK channels dominate in cultured cells with apical exposure. Fourth, duct cell lines originate from adenocarcinomas and/or main ducts and it is not certain whether they have the same phenotype as smaller secretory ducts. Fifth, we need to address the issue of tissue culture and its effect on $\mathrm{P} 2 \mathrm{Y}$ receptors and ion channels that they regulate. In studies on salivary glands, it was shown that duct obstruction, inflammation and culture markedly increase $\mathrm{P}_{2} \mathrm{Y}_{2}$ receptor expression [87, 134, 135]. Also in a recent study on human pancreas it was shown that the pattern for expression of $\mathrm{P}_{2} \mathrm{Y}_{2}$ and $\mathrm{P} 2 \mathrm{X}_{7}$ receptors can change in pathological conditions like chronic pancreatitis, pancreatic cancer and purinergic receptors on other than epithelial cells need to be considered [128]. Lastly, knowledge regarding the expression and physiological function of P2X receptors is lacking for human tissue.

Adenosine receptors There are several studies on the pancreas that have addressed the issue of adenosine receptors. In the intact dog pancreas adenosine modulated secretion evoked by secretin $[136,137]$. Since the effects could also be systemic, e.g. by effecting blood flow, it is not easy to conclude whether the effect is exerted on pancreatic ducts and which adenosine receptors are affected. Nevertheless, using agonists and antagonists for adenosine receptors, it was concluded that $\mathrm{A}_{2 \mathrm{~A}}$ receptors were involved in $\mathrm{HCO}_{3}^{-}$ secretory response. On rat pancreatic lobules, adenosine evoked amylase secretion; this was atropine sensitive, therefore indicating that effects may have been mediated by neural acetylcholine release [138]. Indeed, adenosine response was not found on isolated acini.

Regarding human duct cells, there are some controversies especially regarding $A_{1}$ receptors. Eidelman et al. [139] demonstrated that $A_{1}$ receptor antagonists activated modest $\mathrm{Cl}^{-}$efflux in CFPAC-1 cells, but had no effect in CFPAC-1 cells transfected with CFTR. This would indicate a role for endogenous adenosine, possibly on $\mathrm{Ca}^{2+}$-activated $\mathrm{Cl}^{-}$ channels. A series of substituted derivatives of 1,3,7alkylxanthines was synthesised as potential activators for $\mathrm{Cl}^{-}$efflux in these cells [140]. Among the xanthine derivatives of diverse structure, there was no correlation between potency in $\mathrm{Cl}^{-}$efflux and adenosine antagonism, suggesting that stimulation of $\mathrm{Cl}^{-}$efflux was unrelated to adenosine receptors. In fact it was later reported that xanthines could bind to CFTR directly [141]. In addition, no RNA for the human $A_{1}$ receptor was found [140]. In a latter study also on CFPAC-1 cells, other results were obtained [127]. Adenosine had no effect on $\mathrm{Cl}^{-}$efflux in normal CFPAC-1 cells, but after transfection with CFTR, it stimulated $\mathrm{Cl}^{-}$efflux. Using inhibitors and antagonists for adenosine receptors the results indicate that the effect was due to stimulation of $A_{1}$ and $A_{2}$ (but not $A_{2 A}$ ) receptors. Since no significant increase in cyclic AMP was measured, the authors also suggested that the effects of adenosine may be indirect. Nevertheless, a recent study showed that both rat pancreatic ducts and human duct cell lines expressed low levels of adenosine receptors $A_{1}, A_{2 A}, A_{2 B}$ and $A_{3}$, the most abundant being $A_{2}$ receptors, and it seems that the $A_{2 \mathrm{~A}}$ receptor regulates anion transport $[142,143]$.

\section{Origin and fate of ATP}

As mentioned above, the pancreas is supplied by parasympathetic and sympathetic nerves, which could be the source of ATP and other nucleotides. In addition, rat pancreatic acini release significant amounts of ATP. They do this in response to mechanical stimulation and hypotonic shock, but most importantly, they release ATP in response to acetylcholine and cholecystokinin - the two natural acinar secretagogues in the rat pancreas [144, 145]. It appears that secretion is directed towards the lumen and ATP concentrations in the range of $20 \mu \mathrm{M}$ were detected. Using fluorescent markers for ATP stores, it appears that the secretory granules in acini are a most likely site of ATP, although other stores or other pathways for ATP release are not excluded. Thus acini could provide ATP for the downstream pancreatic ducts expressing P2 receptors on the luminal membrane. In addition to acini, also pancreatic ducts release ATP (unpublished data). They do possess CFTR channels that have been repeatedly in and out of favour as the ATP release channels [146, 147]. Another possibility is that pancreatic ducts distend with oversecretion and release ATP, which then via $\mathrm{P}_{2} \mathrm{Y}_{2}$ receptors and BK channels inhibits further secretion and thus overdistension of ducts $[94,105]$. In contrast to salivary glands that have myoepithelial cells to hold around ducts, pancreatic ducts do not have such support and may rely more on this self-regulation.

Given the high ATP secretion from rat pancreatic acini, it was perhaps surprising to find that pancreatic juice collected from the main common pancreatic/bile duct of the rat pancreas, and also guinea pig and human pancreas, had a low ATP content $[145,148,149]$. A study on the rat 
pancreas showed that CD39 (NTPDase hydrolysing ATP and ADP to AMP) was present luminally on small ducts and basolaterally on larger ducts [148]. In addition, the pancreas secretes ATP-degrading enzymes, CD39 and CD73 (5'-nucleotidase hydrolysing AMP to adenosine), into the juice [145]. CD39 was in fact characterised and purified as one of the first NTPDases from pancreatic tissue (epithelial, endothelial and stromal cells) [150-152]. The origin of secreted enzymes is possibly acinar, as it was shown that CD39 was translocated from plasma membranes and secretory granules towards the lumen and it was secreted into the juice in a particular form, most likely as microvesicles [148]. Along with highly active hydrolytic enzymes, there are also ATP-generating enzymes in pancreatic juice, adenylate kinase and nucleoside diphosphate kinase, capable of sequentially phosphorylating AMP via ADP to ATP [145]. Thus, one would expect that in pancreatic ducts there would be a nucleotide/nucleoside profile favouring ATP and adenosine. Expected concentrations of ADP would be relatively low, which is reflected also by the absence of ADP-preferring receptors [94].

Exocrine pathophysiology and therapeutic potentials

In addition to diabetes, other diseases affecting the pancreas are cystic fibrosis, acute and chronic pancreatitis and pancreatic cancer. Mutations in the CFTR gene lead to aberrant membrane transport and a wide spectrum of diseases affecting epithelia. In the pancreas, faulty $\mathrm{Cl}^{-}$ (and $\mathrm{HCO}_{3}^{-}$) and fluid secretion leads to plugging of ducts by mucus and digestive enzymes, which leads to destruction of acini, inflammation and cystic fibrosis. The main defects in airway epithelia are decreased $\mathrm{Cl}^{-}$and fluid secretion and thus impaired mucociliary clearance and ensuing bacterial infections. One of the treatment strategies for airway epithelia is to develop stable UTP analogues that via $\mathrm{P}_{2} \mathrm{Y}_{2}$ receptors would stimulate $\mathrm{Ca}^{2+}$-activated $\mathrm{Cl}^{-}$ channels as an alternative secretory pathway [153]. Clinical trials show some success with increased mucociliary clearance and forced expiratory volume [154]. Studies on human duct cell lines defective in CFTR indicate that apical application of ATP/UTP could also activate $\mathrm{Ca}^{2+}$-sensitive $\mathrm{Cl}^{-}$channels, although the effect is short lasting. Nevertheless, it would seem difficult to design agonists targeted for the pancreatic duct lumen.

Acute pancreatic injury can lead to a cascade of events beginning with intra-pancreatic activation of zymogens, release of cytokines and other proinflammatory mediators, and ending with systemic inflammatory response and multiple organ failure. The role of adenosine receptors has been investigated in several studies on animal models of pancreatitis. In rats, intraperitoneal administration of a selective $A_{1}$ agonist increased serum amylase and induced morphologic changes in the pancreas characterised by interstitial oedema and leucocyte infiltration-reminiscent of pancreatitis changes [155]. In caerulein- and taurocholateinduced pancreatitis, the $A_{1}$ receptor antagonist significantly reduced pancreatic oedema, although it did not improve the acinar cell damage of the pancreas or the increase of serum amylase. In two studies on caerulein-induced pancreatitis, $\mathrm{A}_{2 \mathrm{~A}}$ receptor stimulation seemed to be protective $[156,157]$.
Fig. 4 Model for nucleotide signalling in the pancreas. Pancreatic acini secrete ATP and also hydrolytic enzymes (CD39 and CD73), which would hydrolyse ATP to adenosine (Ado). Intraluminal ATP can act on luminal $\mathrm{P} 2 \mathrm{X}$ and possibly $\mathrm{P} 2 \mathrm{Y}$ receptors, while the postulated ATP release from distended ducts, as well as ATP released from nerves and from $\beta$ cells, could act on $\mathrm{P} 2 \mathrm{Y}$ receptors on the basolateral side of ducts (modified from [148])

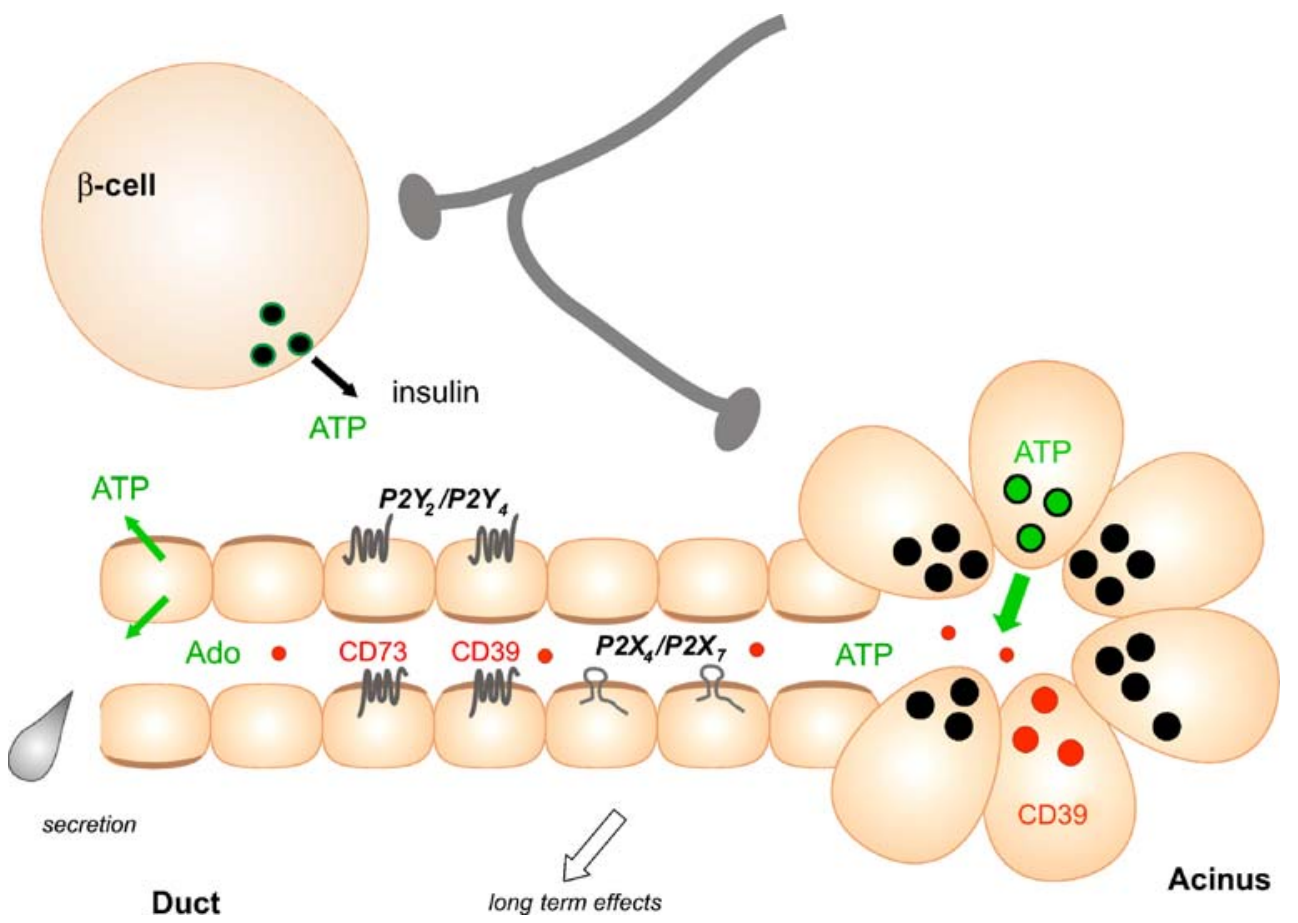


There was an attenuation in the activity of serum amylase, pancreatic weight was less affected and there was a reduced degree of pancreatic tissue damage (oedema, leucocyte infiltration, vacuolization of acinar cells), and also pancreatic blood flow was improved. Another type of experiment also indicates that adenosine levels may be important. An adenosine uptake inhibitor (KF24345) ameliorated the severity and mortality of lethal acute pancreatitis, and this effect was abolished by pretreatment with an $\mathrm{A}_{2 \mathrm{~A}}$ receptor antagonist (ZM 341385) [158]. Taken together, these results at the organ level indicate that endogenous adenosine might have a cytoprotective role in the pancreas, similar to other organs such as the heart and brain [74, 159]. Whether this can be extended to the whole-body level is unclear, as adenosine is a potential mediator of immunosuppression in multiple organ failure, which can follow acute pancreatitis [160].

Recurrent attacks of acute pancreatitis are believed to result in chronic pancreatitis, which is associated with increased risk of developing pancreatic cancer [161, 162]. Extracellular nucleotides have been implicated as inflammatory and stress mediators in many pathological states and thus it is appropriate to look at this in the human pancreas. In a recent study of human material originating from normal pancreas and pancreas from patients with chronic pancreatitis and pancreatic cancer, it was shown that certain NTPDases and P2 receptors were up-regulated [128]. In chronic pancreatitis, CD39 and $\mathrm{P} 2 \mathrm{X}_{7}$ were up-regulated on the mRNA level and some tendencies were also seen on a protein level. $\mathrm{P}_{2} \mathrm{Y}_{2}$ receptors, which were very low in normal pancreas, were up-regulated in pancreatic cancer (both mRNA and protein level). CD39 and CD39L1 were also up-regulated in pancreatic cancer, and patients with high expression of CD39 had longer post-operative survival periods. Immunolocalization with given antibodies showed CD39 distribution in the vasculature and stroma, the $\mathrm{P}_{2} \mathrm{X}_{7}$ receptor was in infiltrating leucocytes and $\mathrm{P}_{2} \mathrm{Y}_{2}$ in fibroblasts adjacent to tumours. These findings implicate distinct roles of CD39 and purinergic signalling in tissue remodelling, fibrogenesis and perhaps tumour development. Future studies will need to clarify apparent lack and disagreement in immunolocalization of NTPDases [128, 163] and P2 receptors in the parenchyma of the human pancreas and human duct cell lines as well as their molecular identity [104]. At least for P2 receptors, numerous functional studies on human and animal ducts show that they are present on the epithelium (see above).

\section{Integrated pancreatic function}

Within the exocrine pancreas, there is evidence that ATP and other components of the purinergic cascade mediate along the acini-duct axis a short-term regulation of secretion. Cholinergic stimulation or cholecystokinin stimulation of acini causes release of ATP, and luminal ATP may lead to up-regulation of secretin-evoked $\mathrm{HCO}_{3}^{-}$and fluid secretion of pancreatic ducts (Fig. 4). This scenario would explain the long-standing observation in pancreatic physiology - the fact that in the intact pancreas the stimulation of acini potentiates the effect of secretin on the production of the $\mathrm{HCO}_{3}^{-}$-rich juice $[164,165]$. Figure 4 shows the working model for how ATP, and/or hydrolytic products as well as the associated enzymes and receptors, could play a role as auto/paracrine regulators in the pancreas. In addition to "within the lumen" signalling, nerves supplying the pancreas could provide nucleotides/ nucleosides necessary for activation of purinergic receptors on the basolateral membranes of pancreatic ducts (and to a limited extent on pancreatic acini). In addition, there are two other potential sources of ATP. One is ATP release from the distended ducts, and this may lead to downregulation of secretion. Another supply may be from endocrine cells. Single endocrine cells are scattered in the epithelium of interlobular ducts. It is now becoming accepted that there is a close anatomical contact between islets and ducts (in addition to islet-acini), and there is an insulo-ductal portal system [166, 167]. Functionally, several islet hormones affect acinar and ductal secretion [166], e.g. insulin potentiates secretin-stimulated secretion in the rat pancreas [165]. Therefore, it is possible that ATP released from $\beta$ cells could affect closely apposed ductal epithelium. Lastly, it is very likely that pathological increases in extracellular nucleotides/sides levels can occur following ductal hypertension, acinar damage and alcohol exposure, and thus can be one of the factors contributing to development of pancreatitis, and chronic pancreatitis is one of the risk factors for development of pancreatic cancer. From a therapeutic point of view, most advances have been made with respect to finding drugs for modulating insulin secretion. Most promising are $\mathrm{P}_{2} \mathrm{Y}_{1}$ receptor analogues that stimulate glucose-dependent insulin secretion in animal models, and thereby have therapeutic potential for treatment of non-insulin-dependent diabetes. This review underpins the complexity and possible interaction in purinergic signalling in the pancreas. Therefore, in order to design selective compounds with good potency and selectivity, molecular subtypes and function of $\mathrm{P} 2$ and adenosine receptors on endocrine and exocrine cells as well as on pancreatic blood vessels, immune cells and pancreatic stellate cells must be known.

Acknowledgements I am grateful to S.E. Hede, M.R. Hansen and C.P. Hansen for criticism of the manuscript. Work of our group cited in this review was supported by the Danish Natural Science Research Council, the Danish Medical Research Council, the Novo Nordisk Foundation and the Lundbeck Foundation. 


\section{References}

1. Githens S (1988) The pancreas duct cell: proliferative capabilities, specific characteristics, metaplasia, isolation, and culture. J Pediatr Gastroenterol Nutr 7:486-506

2. Kodama T (1983) A light and electron microscopic study on the pancreatic ductal system. Acta Pathol Jpn 33:297-321

3. Bouwens L, Pipeleers DG (1998) Extra-insular beta cells associated with ductules are frequent in adult human pancreas. Diabetologia 41:629-633

4. Rondriguez Candela JL, Garcia-Fernandez MC (1963) Stimulation of secretion of insulin by adenosine-triphosphate. Nature 197:1210

5. Levine RA, Oyama S, Kagan A, Glick SM (1970) Stimulation of insulin and growth hormone secretion by adenine nucleotides in primates. J Lab Clin Med 75:30-36

6. Loubatieres-Mariani MM, Chapal J, Lignon F, Valette G (1979) Structural specificity of nucleotides for insulin secretory action from the isolated perfused rat pancreas. Eur J Pharmacol 59:277286

7. Hillaire-Buys D, Chapal J, Petit P, Loubatières-Mariani MM (1994) Purinergic receptors on insulin-secreting cells. Fundam Clin Pharmacol 8:117-127

8. Chapal J, Hillaire-Buys D, Bertrand G, Pujalte D, Petit P, Loubatieres-Mariani MM (1997) Comparative effects of adenosine-5'-triphosphate and related analogues on insulin secretion from the rat pancreas. Fundam Clin Pharmacol 11:537-545

9. Petit P, Bertrand G, Schmeer W, Henquin JC (1989) Effects of extracellular adenine nucleotides on the electrical, ionic and secretory events in mouse pancreatic beta-cells. Br J Pharmacol 98:875-882

10. Fernandez-Alvarez J, Hillaire-Buys D, Loubatieres-Mariani MM, Gomis R, Petit P (2001) P2 receptor agonists stimulate insulin release from human pancreatic islets. Pancreas 22:69-71

11. Farret A, Filhol R, Linck N, Manteghetti M, Vignon J, Gross R, Petit P (2006) P2Y receptor mediated modulation of insulin release by a novel generation of 2-substituted-5'-O-(1-boranotriphosphate)-adenosine analogues. Pharm Res 23:2665-2671

12. Petit P, Hillaire-Buys D, Manteghetti M, Debrus S, Chapal J, Loubatieres-Mariani MM (1998) Evidence for two different types of P2 receptors stimulating insulin secretion from pancreatic B cell. Br J Pharmacol 125:1368-1374

13. Abbracchio MP, Burnstock G, Boeynaems JM, Barnard EA, Boyer JL, Kennedy C, Knight GE, Fumagalli M, Gachet C, Jacobson KA, Weisman GA (2006) International Union of Pharmacology LVIII: update on the P2Y G protein-coupled nucleotide receptors: from molecular mechanisms and pathophysiology to therapy. Pharmacol Rev 58:281-341

14. Fischer B, Chulkin A, Boyer JL, Harden KT, Gendron FP, Beaudoin AR, Chapal J, Hillaire-Buys D, Petit P (1999) 2thioether $5^{\prime}$-O-(1-thiotriphosphate)adenosine derivatives as new insulin secretagogues acting through P2Y-receptors. J Med Chem 42:3636-3646

15. Fischer B, Shahar L, Chulkin A, Boyer JL, Harden KT, Gendron FP, Beaudoin AR, Chapal J, Hillaire-Buys D, Petit P (2000) 2Thioether-5'-O-(1-thiotriphosphate)-adenosine derivatives: new insulin secretagogues acting through P2Y-receptors. Isr Med Assoc J 2(Suppl):92-98

16. Tokuyama Y, Hara M, Jones EM, Fan Z, Bell GI (1995) Cloning of rat and mouse P2Y purinoceptors. Biochem Biophys Res Commun 211:211-218

17. Stam NJ, Klomp J, van de Huevel M, Olijve W (1996) Molecular cloning and characterization of a novel orphan receptor $\left(\mathrm{P}_{2 \mathrm{P}}\right)$ expressed in human pancreas that shows high structural homology to the $\mathrm{P}_{2 \mathrm{U}}$ purinoceptor. FEBS Lett 384:260-264
18. Communi D, Pirotton S, Parmentier M, Boeynaems JM (1995) Cloning and functional expression of a human uridine nucleotide receptor. J Biol Chem 270:30849-30852

19. Verspohl EJ, Johannwille B, Waheed A, Neye H (2002) Effect of purinergic agonists and antagonists on insulin secretion from INS-1 cells (insulinoma cell line) and rat pancreatic islets. Can J Physiol Pharmacol 80:562-568

20. Lugo-Garcia L, Filhol R, Lajoix AD, Gross R, Petit P, Vignon J (2007) Expression of purinergic P2Y receptor subtypes by INS-1 insulinoma beta-cells: a molecular and binding characterization. Eur J Pharmacol 568:54-60

21. Coutinho-Silva R, Parsons M, Robson T, Burnstock G (2001) Changes in expression of $\mathrm{P} 2$ receptors in rat and mouse pancreas during development and ageing. Cell Tissue Res 306:373-383

22. Geschwind JF, Hiriart M, Glennon MC, Najafi H, Corkey BE, Matschinsky FM, Prentki M (1989) Selective activation of $\mathrm{Ca}^{2+}$ influx by extracellular ATP in a pancreatic beta-cell line (HIT). Biochim Biophys Acta 1012:107-115

23. Arkhammar P, Hallberg A, Kindmark H, Nilsson T, Rorsman P, Berggren PO (1990) Extracellular ATP increases cytoplasmic free $\mathrm{Ca}^{2+}$ concentration in clonal insulin-producing RINm5F cells. A mechanism involving direct interaction with both release and refilling of the inositol 1,4,5-trisphosphate-sensitive $\mathrm{Ca}^{2+}$ pool. Biochem J 265:203-211

24. Theler JM, Mollard P, Guerineau N, Vacher P, Pralong WF, Schlegel W, Wollheim CB (1992) Video imaging of cytosolic $\mathrm{Ca}^{2+}$ in pancreatic beta-cells stimulated by glucose, carbachol, and ATP. J Biol Chem 267:18110-18117

25. Wang CZ, Namba N, Gonoi T, Inagaki N, Seino S (1996) Cloning and pharmacological characterization of a fourth P2X receptor subtype widely expressed in brain and peripheral tissues including various endocrine tissues. Biochem Biophys Res Commun 220:196-202

26. Coutinho-Silva R, Parsons M, Robson T, Lincoln J, Burnstock G (2003) P2X and P2Y purinoceptor expression in pancreas from streptozotocin-diabetic rats. Mol Cell Endocrinol 204:141-154

27. Coutinho-Silva R, Robson T, Beales PE, Burnstock G (2007) Changes in expression of $\mathrm{P} 2 \mathrm{X} 7$ receptors in NOD mouse pancreas during the development of diabetes. Autoimmunity 40:108-116

28. Cheung KK, Coutinho-Silva R, Chan WY, Burnstock G (2007) Early expression of adenosine 5'-triphosphate-gated P2X7 receptors in the developing rat pancreas. Pancreas 35:164-168

29. Li GD, Milani D, Dunne MJ, Pralong WF, Theler JM, Petersen OH, Wollheim CB (1991) Extracellular ATP causes $\mathrm{Ca}^{2+}$. dependent and -independent insulin secretion in RINm5F cells. Phospholipase $\mathrm{C}$ mediates $\mathrm{Ca}^{2+}$ mobilization but not $\mathrm{Ca}^{2+}$ influx and membrane depolarization. J Biol Chem 266:3449-3457

30. Thore S, Dyachok O, Tengholm A (2004) Oscillations of phospholipase $\mathrm{C}$ activity triggered by depolarization and $\mathrm{Ca}^{2+}$ influx in insulin-secreting cells. J Biol Chem 279:19396-19400

31. Xie L, Zhang M, Zhou W, Wu Z, Ding J, Chen L, Xu T (2006) Extracellular ATP stimulates exocytosis via localized $\mathrm{Ca}^{2+}$ release from acidic stores in rat pancreatic beta cells. Traffic 7:429-439

32. Chevassus H, Roig A, Belloc C, Lajoix AD, Broca C, Manteghetti M, Petit P (2002) P2Y receptor activation enhances insulin release from pancreatic beta-cells by triggering the cyclic AMP/protein kinase A pathway. Naunyn Schmiedebergs Arch Pharmacol 366:464-469

33. Dyachok O, Isakov Y, Sagetorp J, Tengholm A (2006) Oscillations of cyclic AMP in hormone-stimulated insulinsecreting beta-cells. Nature 439:349-352

34. Farret A, Vignaud M, Dietz S, Vignon J, Petit P, Gross R (2004) P2Y purinergic potentiation of glucose-induced insulin secretion and pancreatic beta-cell metabolism. Diabetes 53(Suppl 3):S63-S66 
35. Poulsen CR, Bokvist K, Olsen HL, Hoy M, Capito K, Gilon P, Gromada J (1999) Multiple sites of purinergic control of insulin secretion in mouse pancreatic beta-cells. Diabetes 48:2171-2181

36. Hauge-Evans AC, Squires PE, Belin VD, Roderigo-Milne H, Ramracheya RD, Persaud SJ, Jones PM (2002) Role of adenine nucleotides in insulin secretion from MIN6 pseudoislets. Mol Cell Endocrinol 191:167-176

37. Zhao YF, Xu R, Hernandez M, Zhu Y, Chen C (2003) Distinct intracellular $\mathrm{Ca}^{2+}$ response to extracellular adenosine triphosphate in pancreatic beta-cells in rats and mice. Endocrine 22:185-192

38. Léon C, Freund M, Latchoumanin O, Farret A, Petit P, Cazenne $\mathrm{J}-\mathrm{P}$, Gachet $\mathrm{C}(2005)$ The $\mathrm{P}_{2} \mathrm{Y}_{1}$ receptor is involved in the maintenance of glucose homeostasis and insulin secretion in mice. Purinergic Signalling 1:145-151

39. Bacher S, Kraupp O, Conca W, Raberger G (1982) The effects of NECA (adenosine- $5^{\prime} \mathrm{N}$-ethylcarboxamide) and of adenosine on glucagon and insulin release from the in situ isolated bloodperfused pancreas in anesthetized dogs. Naunyn Schmiedebergs Arch Pharmacol 320:67-71

40. Bertrand G, Petit P, Bozem M, Henquin JC (1989) Membrane and intracellular effects of adenosine in mouse pancreatic betacells. Am J Physiol 257:E473-E478

41. Chapal J, Loubatieres-Mariani MM, Roye M, Zerbib A (1984) Effects of adenosine, adenosine triphosphate and structural analogues on glucagon secretion from the perfused pancreas of rat in vitro. Br J Pharmacol 83:927-933

42. Chapal J, Loubatieres-Mariani MM, Petit P, Roye M (1985) Evidence for an A2-subtype adenosine receptor on pancreatic glucagon secreting cells. Br J Pharmacol 86:565-569

43. Bertrand G, Gross R, Ribes G, Loubatieres-Mariani MM (1990) P2 purinoceptor agonists stimulate somatostatin secretion from dog pancreas. Eur J Pharmacol 182:369-373

44. Munoz A, Hu M, Hussain K, Bryan J, Aguilar-Bryan L, Rajan AS (2005) Regulation of glucagon secretion at low glucose concentrations: evidence for adenosine triphosphate-sensitive potassium channel involvement. Endocrinology 146:5514-5521

45. Gromada J, Ma X, Hoy M, Bokvist K, Salehi A, Berggren PO, Rorsman P (2004) ATP-sensitive K+ channel-dependent regulation of glucagon release and electrical activity by glucose in wild-type and SUR1-/- mouse alpha-cells. Diabetes 53(Suppl 3): S181-S189

46. Hillaire-Buys D, Gross R, Pares-Herbute N, Ribes G, LoubatieresMariani MM (1994) In vivo and in vitro effects of adenosine-5'-O(2-thiodiphosphate) on pancreatic hormones in dogs. Pancreas 9:646-651

47. Bodin P, Burnstock G (2001) Purinergic signalling: ATP release. Neurochem Res 26:959-969

48. White TD, MacDonald WF (1990) Neural release of ATP and adenosine. Ann N Y Acad Sci 603:287-299

49. Zimmermann H (1982) Biochemistry of isolated cholinergic vesicles. In: Klein RL, Lagercrantz H, Zimmermann H (eds) Neurotransmitter vesicles. Academic, London, pp 271-302

50. Bertrand G, Chapal J, Loubatieres-Mariani MM (1986) Potentiating synergism between adenosine diphosphate or triphosphate and acetylcholine on insulin secretion. Am J Physiol 251:E416E421

51. Leitner JW, Sussman KE, Vatter AE, Schneider FH (1975) Adenine nucleotides in the secretory granule fraction of rat islets. Endocrinology 96:662-677

52. Hazama A, Hayashi S, Okada Y (1998) Cell surface measurements of ATP release from single pancreatic beta cells using a novel biosensor technique. Pflugers Arch 437:31-35

53. Detimary P, Jonas J-C, Henquin J-C (1995) Possible links between glucose-induced changes in the energy state of pancreatic B cells and insulin release. J Clin Invest 96:1738-1745
54. Detimary P, Jonas JC, Henquin JC (1996) Stable and diffusible pools of nucleotides in pancreatic islet cells. Endocrinology 137:4671-4676

55. Obermuller S, Lindqvist A, Karanauskaite J, Galvanovskis J, Rorsman P, Barg S (2005) Selective nucleotide-release from dense-core granules in insulin-secreting cells. J Cell Sci 118:4271-4282

56. Porksen N, Hollingdal M, Juhl C, Butler P, Veldhuis JD, Schmitz O (2002) Pulsatile insulin secretion: detection, regulation, and role in diabetes. Diabetes 51 Suppl 1:S245-S254

57. Gilon P, Shepherd RM, Henquin JC (1993) Oscillations of secretion driven by oscillations of cytoplasmic $\mathrm{Ca}^{2+}$ as evidences in single pancreatic islets. J Biol Chem 268:22265-22268

58. Kjems LL, Ravier MA, Jonas JC, Henquin JC (2002) Do oscillations of insulin secretion occur in the absence of cytoplasmic $\mathrm{Ca}^{2+}$ oscillations in beta-cells? Diabetes 51(Suppl 1): S177-S182

59. Ravier MA, Guldenagel M, Charollais A, Gjinovci A, Caille D, Sohl G, Wollheim CB, Willecke K, Henquin JC, Meda P (2005) Loss of connexin36 channels alters beta-cell coupling, islet synchronization of glucose-induced $\mathrm{Ca}^{2+}$ and insulin oscillations, and basal insulin release. Diabetes 54:1798-1807

60. Hellman B, Dansk H, Grapengiesser E (2004) Pancreatic betacells communicate via intermittent release of ATP. Am J Physiol Endocrinol Metab 286:E759-E765

61. Ashcroft F, Rorsman P (2004) Type 2 diabetes mellitus: not quite exciting enough? Hum Mol Genet 13(Spec No 1):R21-R31

62. Salehi A, Qader SS, Grapengiesser E, Hellman B (2005) Inhibition of purinoceptors amplifies glucose-stimulated insulin release with removal of its pulsatility. Diabetes 54:2126-2131

63. Quesada I, Todorova MG, Alonso-Magdalena P, Beltra M, Carneiro EM, Martin F, Nadal A, Soria B (2006) Glucose induces opposite intracellular $\mathrm{Ca}^{2+}$ concentration oscillatory patterns in identified alpha- and beta-cells within intact human islets of Langerhans. Diabetes 55:2463-2469

64. Grapengiesser E, Salehi A, Qader SS, Hellman B (2006) Glucose induces glucagon release pulses antisynchronous with insulin and sensitive to purinoceptor inhibition. Endocrinology 147: 3472-3477

65. Doyle ME, Egan JM (2003) Pharmacological agents that directly modulate insulin secretion. Pharmacol Rev 55:105-131

66. Henquin JC (2004) Pathways in beta-cell stimulus-secretion coupling as targets for therapeutic insulin secretagogues. Diabetes 53(Suppl 3):S48-S58

67. Farret A, Lugo-Garcia L, Galtier F, Gross R, Petit P (2005) Pharmacological interventions that directly stimulate or modulate insulin secretion from pancreatic beta-cell: implications for the treatment of type 2 diabetes. Fundam Clin Pharmacol 19:647-656

68. Hillaire-Buys D, Bertrand G, Chapal J, Puech R, Ribes G, Loubatieres-Mariani MM (1993) Stimulation of insulin secretion and improvement of glucose tolerance in rat and dog by the P2ypurinoceptor agonist, adenosine-5'-O-(2-thiodiphosphate). Br J Pharmacol 109:183-187

69. Tang J, Pugh W, Polonsky KS, Zhang H (1996) Preservation of insulin secretory responses to $\mathrm{P} 2$ purinoceptor agonists in Zucker diabetic fatty rats. Am J Physiol 270:E504-E512

70. Squires PE, James RF, London NJ, Dunne MJ (1994) ATPinduced intracellular $\mathrm{Ca} 2+$ signals in isolated human insulinsecreting cells. Pflugers Arch 427:181-183

71. Hillaire-Buys D, Chapal J, Linck N, Blayac JP, Petit P, Loubatieres-Mariani MM (1998) Involvement of $\mathrm{K}+$ channel permeability changes in the L-NAME and indomethacin resistant part of adenosine-5'-O-(2-thiodiphosphate)-induced relaxation of pancreatic vascular bed. Br J Pharmacol 124:149-156

72. Cerasi E, Luft R (1969) The effect of an adenosine-3'5'monophosphate diesterase inhibitor (aminophylline) on the 
insulin response to glucose infusion in prediabetic and diabetic subjects. Horm Metab Res 1:162-168

73. Arias AM, Bisschop PH, Ackermans MT, Nijpels G, Endert E, Romijn JA, Sauerwein HP (2001) Aminophylline stimulates insulin secretion in patients with type 2 diabetes mellitus. Metabolism 50:1030-1035

74. Jacobson KA, Gao ZG (2006) Adenosine receptors as therapeutic targets. Nat Rev Drug Discov 5:247-264

75. Novak I (2003) ATP as a signaling molecule-the exocrine focus. News Physiol Sci 18:12-17

76. Novak I, Amstrup J, Henriksen KL, Hede SE, Sørensen CE (2003) ATP release and effects in pancreas. Drug Dev Res 59:128-135

77. Novak I, Nitschke R, Amstrup J (2002) Purinergic receptors have different effects in rat exocrine pancreas. Calcium signals monitored by Fura-2 in confocal microscope. Cell Physiol Biochem 12:83-92

78. Tenneti L, Gibbons SJ, Talamo BR (1998) Expression and transsynaptic regulation of $\mathrm{P} 2 \mathrm{x} 4$ and $\mathrm{P} 2 \mathrm{z}$ receptors for extracellular ATP in parotid acinar cells. Effects of parasympathetic denervation. J Biol Chem 273:26799-26808

79. Sasaki T, Gallacher DV (1990) Extracellular ATP activates receptor-operated cation channels in mouse lacrimal acinar cells to promote calcium influx in the absence of phophoinositide metabolism. FEBS Lett 264:130-134

80. Vincent P (1992) Cationic channels sensitive to extracellular ATP in rat lacrimal cells. J Physiol (Lond) 449:313-331

81. Brown DA, Bruce JI, Straub SV, Yule DI (2004) cAMP potentiates ATP-evoked calcium signaling in human parotid acinar cells. J Biol Chem 279:39485-39494

82. Sorensen CE, Novak I (2001) Visualization of ATP release in pancreatic acini in response to cholinergic stimulus. Use of fluorescent probes and confocal microscopy. J Biol Chem 276:329525-329532

83. Jørgensen TD, Gromada J, Tritsaris K, Nauntofte B, Dissing S (1995) Activation of $\mathrm{P}_{2 z}$ purinoreceptor diminishes the muscarinic cholinergic-induced release of inositol 1,4,5-triphosphate and stored calcium in rat parotid acini. Biochem J 312:457-464

84. Soltoff SP, McMillan MK, Talamo BR (1992) ATP activates a cation-permeable pathway in rat parotid acinar cells. Am J Physiol Cell Physiol 262:C934-C940

85. Lee MG, Zeng W, Muallem S (1997) Characterization and localization of $\mathrm{P} 2$ receptors in rat submandibular gland acinar and duct cells. J Biol Chem 272:32951-32955

86. Buell G, Lewis C, Collo G, North RA, Surprenant A (1996) An antagonist-insensitive $\mathrm{P} 2 \mathrm{X}$ receptor expressed in epithelia and brain. EMBO J 15:55-62

87. Turner JT, Weisman GA, Camden JM (1997) Upregulation of $\mathrm{P}_{2} \mathrm{Y}_{2}$ nucleotide receptors in rat salivary gland cells during short-term culture. Am J Physiol 273:C1100-C1107

88. Park MK, Garrad RC, Weisman GA, Turner JT (1997) Changes in P2Y1 nucleotide receptor activity during the development of rat salivary glands. Am J Physiol 272:C1388-C1393

89. Worthington RA, Dutton JL, Poronnik P, Bennett MR, Barden JA (1999) Localisation of P2X receptors in human salivary gland epithelial cells and human embryonic kidney cells by sodium dodecyl sulfate-polyacrylamide gel electrophoresis/Western blotting and immunofluorescence. Electrophoresis 20:20652070

90. Slater M, Barden JA, Murphy CR (2000) The purinergic calcium channels P2X1,2,5,7 are down-regulated while P2X3,4,6 are upregulated during apoptosis in the ageing rat prostate. Histochem J 32:571-580

91. Hug M, Pahl C, Novak I (1994) Effect of ATP, carbachol and other agonists on intracellular calcium activity and membrane voltage of pancreatic ducts. Pflugers Arch 426:412-418
92. Hug MJ, Pahl C, Novak I (1996) Calcium influx pathways in rat pancreatic ducts. Pflugers Arch 432:278-285

93. Christoffersen BC, Hug MJ, Novak I (1998) Different purinergic receptors lead to intracellular calcium increases in pancreatic ducts. Pflugers Arch 436:33-39

94. Hede SE, Amstrup J, Christoffersen BC, Novak I (1999) Purinoceptors evoke different electrophysiological responses in pancreatic ducts. $\mathrm{P} 2 \mathrm{Y}$ inhibits $\mathrm{K}^{+}$conductance, and $\mathrm{P} 2 \mathrm{X}$ stimulates cation conductance. J Biol Chem 274:31784-31791

95. North RA (2002) Molecular physiology of P2X receptors. Physiol Rev 82:1013-1067

96. Luo X, Zheng W, Yan M, Lee MG, Muallem S (1999) Multiple functional P2X and P2Y receptors in the luminal and basolateral membranes of pancreatic duct cells. Am J Physiol 277:C205$\mathrm{C} 215$

97. Novak I, Greger R (1988) Properties of the luminal membrane of isolated perfused rat pancreatic ducts: effect of cyclic AMP and blockers of chloride transport. Pflugers Arch 411:546-553

98. Steward MC, Ishiguro H, Case RM (2005) Mechanisms of bicarbonate secretion in the pancreatic duct. Annu Rev Physiol 67:377-409

99. Novak I, Greger R (1991) Effect of bicarbonate on potassium conductance of isolated perfused rat pancreatic ducts. Pflugers Arch 419:76-83

100. Gray MA, Greenwell JR, Garton AJ, Argent BE (1990) Regulation of maxi- $\mathrm{K}^{+}$channels on pancreatic duct cells by cyclic AMP-dependent phosphorylation. J Membr Biol 115:203215

101. Nguyen TD, Moody MW (1998) Calcium-activated potassium conductances on cultured nontransformed dog pancreatic duct epithelial cells. Pancreas 17:348-358

102. Fong P, Argent BE, Guggino WB, Gray MA (2003) Characterization of vectorial chloride transport pathways in the human pancreatic duct adenocarcinoma cell line, HPAF. Am J Physiol Cell Physiol 285:C433-C445

103. Ishiguro $H$, Naruse $\mathrm{S}$, Kitagawa M, Hayakawa T, Case RM, Steward MC (1999) Luminal ATP stimulates fluid and $\mathrm{HCO}_{3}^{-}$ secretion in guinea-pig pancreatic duct. J Physiol (Lond) 519:551-558

104. Szucs A, Demeter I, Burghardt B, Ovari G, Case RM, Steward MC, Varga G (2006) Vectorial bicarbonate transport by Capan-1 cells: a model for human pancreatic ductal secretion. Cell Physiol Biochem 18:253-264

105. Hede SE, Amstrup J, Klaerke DA, Novak I (2005) P2 $\mathrm{Y}_{2}$ and $\mathrm{P}_{2} \mathrm{Y}_{4}$ receptors regulate pancreatic $\mathrm{Ca}^{2+}$-activated $\mathrm{K}^{+}$channels differently. Pflugers Arch 450:429-436

106. Erb L, Liao Z, Seye CI, Weisman GA (2006) P2 receptors: intracellular signaling. Pflugers Arch 452:552-562

107. Van Kolen K, Slegers H (2006) Integration of P2Y receptoractivated signal transduction pathways in $\mathrm{G}$ protein-dependent signalling networks. Purinergic Signalling 2:451-469

108. Hegyi P, Rakonczay Z Jr, Tiszlavicz L, Varro A, Toth A, Racz G, Varga G, Gray MA, Argent BE (2005) Protein kinase C mediates the inhibitory effect of substance $\mathrm{P}$ on $\mathrm{HCO}_{3}^{-}$secretion from guinea pig pancreatic ducts. Am J Physiol Cell Physiol 288: C1030-C1041

109. Sabbatini ME, Vatta MS, Davio CA, Bianciotti LG (2007) Atrial natriuretic factor negatively modulates secretin intracellular signaling in the exocrine pancreas. Am J Physiol Gastrointest Liver Physiol 292:G349-G357

110. Cook DI, Young JA (1989) Effect of $\mathrm{K}^{+}$channels in the apical plasma membrane on epithelial secretion based on secondary active Cl- transport. J Membr Biol 110:139-146

111. Henriksen KL, Novak I (2003) Effect of ATP on intracellular pH in pancreatic ducts involves $\mathrm{P} 2 \mathrm{X} 7$ receptors. Cell Physiol Biochem 13:93-102 
112. Amstrup J, Novak I (2003) $\mathrm{P} 2 \mathrm{X}_{7}$ receptor activates extracelluar signal-regulated kinases ERK1 and ERK2 independently of $\mathrm{Ca}^{2+}$ influx. Biochem J 374:51-61

113. Khakh BS, North RA (2006) P2X receptors as cell-surface ATP sensors in health and disease. Nature 442:527-532

114. Seufferlein T (2002) Novel protein kinases in pancreatic cell growth and cancer. Int $\mathrm{J}$ Gastrointest Cancer 31:15-21

115. Racz GZ, Szucs A, Szlavik V, Vag J, Burghardt B, Elliott AC, Varga G (2006) Possible role of duration of PKC-induced ERK activation in the effects of agonists and phorbol esters on DNA synthesis in Panc-1 cells. J Cell Biochem 98:1667-1680

116. Kisfalvi K, Guha S, Rozengurt E (2005) Neurotensin and EGF induce synergistic stimulation of DNA synthesis by increasing the duration of ERK signaling in ductal pancreatic cancer cells. $J$ Cell Physiol 202:880-890

117. Elssner A, Duncan M, Gavrilin M, Wewers MD (2004) A novel $\mathrm{P} 2 \mathrm{X} 7$ receptor activator, the human cathelicidin-derived peptide LL37, induces IL-1 beta processing and release. J Immunol 172:4987-4994

118. Murakami M, Ohtake T, Dorschner RA, Gallo RL (2002) Cathelicidin antimicrobial peptides are expressed in salivary glands and saliva. J Dent Res 81:845-850

119. Li Q, Luo X, Muallem S (2005) Regulation of the P2X7 receptor permeability to large molecules by extracellular $\mathrm{Cl}-$ and $\mathrm{Na}+$. $\mathrm{J}$ Biol Chem 280:26922-26927

120. Pochet S, Tandel S, Querriere S, Tre-Hardy M, Garcia-Marcos M, De Lorenzi M, Vandenbranden M, Marino A, Devleeschouwer M, Dehaye JP (2006) Modulation by LL-37 of the responses of salivary glands to purinergic agonists. Mol Pharmacol 69:2037-2046

121. Li Q, Luo X, Zeng W, Muallem S (2003) Cell-specific behavior of P2X7 receptors in mouse parotid acinar and duct cells. J Biol Chem 278:47554-47561

122. Galietta LJ, Zegarra-Moran O, Mastrocola T, Wohrle C, Rugolo M, Romeo G (1994) Activation of $\mathrm{Ca}^{2+}$-dependent $\mathrm{K}^{+}$and $\mathrm{Cl}^{-}$ currents by UTP and ATP in CFPAC-1 cells. Pflugers Arch 426:534-541

123. Warth R, Greger R (1993) The ion conductances of CFPAC-1 cells. Cell Physiol Biochem 3:2-16

124. Chan HC, Cheung WT, Leung PY, Wu LJ, Chew SB, Ko WH, Wong PY (1996) Purinergic regulation of anion secretion by cystic fibrosis pancreatic duct cells. Am J Physiol 271:C469-C477

125. Zsembery A, Strazzabosco M, Graf J (2000) $\mathrm{Ca}^{2+}$-activated $\mathrm{Cl}^{-}$ channels can substitute for CFTR in stimulation of pancreatic duct bicarbonate secretion. FASEB J 14:2345-2356

126. Namkung W, Lee JA, Ahn W, Han W, Kwon SW, Ahn DS, Kim $\mathrm{KH}$, Lee MG (2003) $\mathrm{Ca}^{2+}$ activates cystic fibrosis transmembrane conductance regulator- and Cl- -dependent $\mathrm{HCO} 3$ transport in pancreatic duct cells. J Biol Chem 278:200-207

127. O'Reilly CM, O'Farrell AM, Ryan MP (1998) Purinoceptor activation of chloride transport in cystic fibrosis and CFTRtransfected pancreatic cell lines. Br J Pharmacol 124:15971606

128. Kunzli BM, Berberat PO, Giese T, Csizmadia E, Kaczmarek E, Baker C, Halaceli I, Buchler MW, Friess H, Robson SC (2007) Upregulation of CD39/NTPDases and P2 receptors in human pancreatic disease. Am J Physiol Gastrointest Liver Physiol 292: G223-G230

129. Montserrat C, Merten M, Figarella C (1996) Defective ATPdependent mucin secretion by cystic fibrosis pancreatic epithelial cells. FEBS Lett 393:264-268

130. Jung SR, Kim MH, Hille B, Nguyen TD, Koh DS (2004) Regulation of exocytosis by purinergic receptors in pancreatic duct epithelial cells. Am J Physiol Cell Physiol 286:C573C579

131. Jung SR, Kim K, Hille B, Nguyen TD, Koh DS (2006) Pattern of $\mathrm{Ca}^{2+}$ increase determines the type of secretory mechanism activated in dog pancreatic duct epithelial cells. J Physiol 576:163-178

132. Nguyen TD, Moody MW, Savard CE, Lee SP (1998) Secretory effects of ATP on nontransformed dog pancreatic duct epithelial cells. Am J Physiol 275:G104-G113

133. Nguyen TD, Meichle S, Kim US, Wong T, Moody MW (2001) $\mathrm{P} 2 \mathrm{Y}_{11}$, a purinergic receptor acting via cAMP, mediates secretion by pancreatic duct epithelial cells. Am J Physiol Gastrointest Liver Physiol 280:G795-G804

134. Ahn JS, Camden JM, Schrader AM, Redman RS, Turner JT (2000) Reversible regulation of P2Y2 nucleotide receptor expression in the duct-ligated rat submandibular gland. Am J Physiol Cell Physiol 279:C286-C294

135. Schrader AM, Camden JM, Weisman GA (2005) P2Y2 nucleotide receptor up-regulation in submandibular gland cells from the NOD.B10 mouse model of Sjögren's syndrome. Arch Oral Biol 50:533-540

136. Yamagishi F, Homma N, Haruta K, Iwatsuki K, Chiba S (1986) Effects of three purine-related compounds on pancreatic exocrine secretion in the dog. Clin Exp Pharmacol Physiol 13:425-432

137. Yamagishi F, Homma N, Haruta K, Iwatsuki K, Chiba S (1985) Adenosine potentiates secretin-stimulated pancreatic exocrine secretion in the dog. Eur J Pharmacol 118:203-209

138. Rodriguez-Nodal F, San Roman JI, Lopez-Novoa JM, Calvo JJ (1995) Effect of adenosine and adenosine agonists on amylase release from rat pancreatic lobules. Life Sci 57:L253-L258

139. Eidelman O, Guay-Broder C, van Galen PJ, Jacobson KA, Fox C, Turner RJ, Cabantchik ZI, Pollard HB (1992) A1 adenosinereceptor antagonists activate chloride efflux from cystic fibrosis cells. Proc Natl Acad Sci U S A 89:5562-5566

140. Jacobson K, Guay-Broder C, van Galen P, Gallo-Rodriquez C, Melan N, Jacobson M, Eidelman O, Pollard HB (1995) Stimulation by alkylxanthines of chloride efflux in CFPAC-1 cells does not involve A1 adenosine receptors. Biochemistry 34:9088-9094

141. Cohen BE, Lee G, Jacobson KA, Kim YC, Huang Z, Sorscher EJ, Pollard HB (1997) 8-cyclopentyl-1,3-dipropylxanthine and other xanthines differentially bind to the wild-type and delta F508 first nucleotide binding fold (NBF-1) domains of the cystic fibrosis transmembrane conductance regulator. Biochemistry 36:6455-6461

142. Novak I, Hede SE, Hansen MR (2006) Adenosine receptors in exocrine pancreas. Purinergic Signalling 2:111

143. Novak I, Hede SE, Hansen MR (2007) Adenosine receptors in rat and human pancreatic ducts stimulate chloride transport. Pflügers Arch. (in press)

144. Sørensen CE, Novak I (2001) Visualization of ATP release in pancreatic acini in response to cholinergic stimulus. Use of fluorescent probes and confocal microscopy. J Biol Chem 276:32925-32932

145. Yegutkin GG, Samburski SS, Jalkalen S, Novak I (2006) ATPconsuming and ATP-generating enzymes secreted by pancreas. J Biol Chem 281:29441-29447

146. Schwiebert EM, Zsembery A (2002) Extracellular ATP as a signaling molecule for epithelial cells. Biochim Biophys Acta 1615:7-32

147. Sabirov RS, Okada Y (2005) ATP release via anion channels. Purinergic Signalling 1:311-328

148. Sørensen CE, Amstrup J, Rasmussen HN, Ankorina-Stark I, Novak I (2003) Rat pancreas secretes particulate ecto-nucleotidase CD39. J Physiol 551(3):881-892

149. Kordas KS, Sperlagh B, Tihanyi T, Topa L, Steward MC, Varga G, Kittel A (2004) ATP and ATPase secretion by exocrine pancreas in rat, guinea pig, and human. Pancreas 29:53-60

150. Hamlyn JM, Senior AE (1983) Evidence that $\mathrm{Mg}^{2+}-$ or $\mathrm{Ca}^{2+}$ activated adenosine triphosphatase in rat pancreas is a plasmamembrane ecto-enzyme. Biochem J 214:59-68 
151. Laliberté JF, St Jean P, Beaudoin AR (1982) Kinetic effects of $\mathrm{Ca}^{2+}$ and $\mathrm{Mg}^{2+}$ on ATP hydrolysis by the purified ATP diphosphohydrolase. J Biol Chem 257:3869-3874

152. Sévigny J, Cote YP, Beaudoin AR (1995) Purification of pancreas type-I ATP diphosphohydrolase and identification by affinity labelling with the 5-p-fluorosulphonylbenzoyladenosine ATP. Biochem J 312:351-356

153. Boucher RC (2004) New concepts of the pathogenesis of cystic fibrosis lung disease. Eur Respir J 23:146-158

154. Deterding R, Retsch-Bogart G, Milgram L, Gibson R, Daines C, Zeitlin PL, Milla C, Marshall B, Lavange L, Engels J, Mathews D, Gorden J, Schaberg A, Williams J, Ramsey B (2005) Safety and tolerability of denufosol tetrasodium inhalation solution, a novel P2Y2 receptor agonist: results of a phase 1/phase 2 multicenter study in mild to moderate cystic fibrosis. Pediatr Pulmonol 39:339-348

155. Satoh A, Shimosegawa T, Satoh K, Ito H, Kohno Y, Masamune A, Fujita M, Toyota T (2000) Activation of adenosine A1receptor pathway induces edema formation in the pancreas of rats. Gastroenterology 119:829-836

156. Celinski K, Szczerbinski M, Slomka M, Kasztelan-Szczerbinska B (2003) The role of adenosine receptors for pancreatic blood flow in caerulein-induced acute pancreatitis. Rocz Akad Med Bialymst 48:57-60

157. Satoh A, Satoh K, Masamune A, Yamagiwa T, Shimosegawa $T$ (2002) Activation of adenosine A2a receptor pathway reduces leukocyte infiltration but enhances edema formation in rat caerulein pancreatitis. Pancreas 24:75-82

158. Noji T, Nan-ya K, Mizutani M, Katagiri C, Sano J, Takada C, Nishikawa S, Karasawa A, Kusaka H (2002) KF24345, an adenosine uptake inhibitor, ameliorates the severity and mortality of lethal acute pancreatitis via endogenous adenosine in mice. Eur J Pharmacol 454:85-93

159. Fredholm BB, IJzerman AP, Jacobson KA, Klotz KN, Linden J (2001) International Union of Pharmacology. XXV. Nomenclature and classification of adenosine receptors. Pharmacol Rev 53:527-552

160. Hasko G, Deitch EA, Szabo C, Nemeth ZH, Vizi ES (2002) Adenosine: a potential mediator of immunosuppression in multiple organ failure. Curr Opin Pharmacol 2:440-444

161. Lowenfels AB, Maisonneuve P, Cavallini G, Ammann RW, Lankisch PG, Andersen JR, DiMagno EP, Andren-Sandberg A, Domellof L (1993) Pancreatitis and the risk of pancreatic cancer. International Pancreatitis Study Group. N Engl J Med 328:14331437

162. Maisonneuve P, Lowenfels AB (2002) Chronic pancreatitis and pancreatic cancer. Dig Dis 20:32-37

163. Kittel A, Garrido M, Varga G (2002) Localization fo NTPDase1/ CD39 in normal and transformed human pancreas. J Histochem Cytochem 50:549-555

164. Chey WY, Kim MS, Lee KY (1979) Influence of the vagus nerve on release and action of secretin in dog. J Physiol (Lond) 293:435-446

165. Park HS, Lee YL, Kwon HY, Chey WY, Park HJ (1998) Significant cholinergic role in secretin-stimulated exocrine secretion in isolated rat pancreas. Am J Physiol 274:G413-G418

166. Bertelli E, Bendayan M (2005) Association between endocrine pancreas and ductal system. More than an epiphenomenon of endocrine differentiation and development? J Histochem Cytochem 53:1071-1086

167. Ohtani O, Wang QX (1997) Comparative analysis of insuloacinar portal system in rats, guinea pigs, and dogs. Microsc Res Tech 37:489-496 